\title{
Adsorption of Acid Red 35 (AR35) dye onto Mandarin Biochar-TETA (MBT) derived from Mandarin peels
}

\section{Murat Yılmaz}

Osmania University

Tarek M. Eldeeb

National Institute of Oceanography and Fisheries Alexandria Branch: National Institute of Oceanography and Fisheries Mediterranean Sea Branch

\section{Mohamed A. Hassaan}

National Institute of Oceanography and Fisheries Alexandria Branch: National Institute of Oceanography and Fisheries Mediterranean Sea Branch

\section{Mohamed A. El-Nemr}

Minia University Faculty of Engineering

\section{Safaa Ragab}

National Institute of Oceanography and Fisheries Alexandria Branch: National Institute of Oceanography and Fisheries Mediterranean Sea Branch

Ahmed El Nemr ( $\square$ ahmedmoustafaelnemr@yahoo.com )

National Institute of Oceanography and Fisheries https://orcid.org/0000-0003-2373-5846

\section{Research Article}

Keywords: Mandarin peels, Biochar-TETA, Acid Red 35 dye, Triethylenetetramine, Dehydrated Biochar

Posted Date: February 9th, 2022

DOI: https://doi.org/10.21203/rs.3.rs-1324698/v1

License: (c) (1) This work is licensed under a Creative Commons Attribution 4.0 International License. Read Full License 


\section{Abstract}

In this study, a new biochar was produced from mandarin peel residues by dehydration with $50 \%$ sulfuric acid followed by decoration with oxidation then reaction with TETA. The effect of the obtained new biochar on the ability to remove AR35 dye from the aqueous solution was investigated. The prepared Mandarin Biochar-TETA (MBT) was characterized by FT-IR, BJH, BET, SEM, DSC, TGA, XRD and EDX analyses. The optimum $\mathrm{pH}$ value for AR35 dye adsorption was determined as 1.5. The highest removal percentage of AR35 dye was $97.50 \%$ using $300 \mathrm{mg} \mathrm{L}^{-1}$ AR35 dye initial concentration and $2.5 \mathrm{~g} \mathrm{~L}^{-1} \mathrm{MBT}$ dose. The MBT had a maximum adsorption capacity $\left(Q_{m}\right)$ of $476.19 \mathrm{mg} \mathrm{g}^{-1}$. The data obtained were analyzed with Langmuir, Freundlich, Tempkin, Dubinin-Radushkevich and Jovanovic isotherm models. In addition, the data obtained from these isotherm models were tested using different error functions (hybrid error function (HYBRID), average percent errors (APE), the sum of the absolute errors (EABS), Chi-square error $\left(\mathrm{X}^{2}\right)$, the root mean square errors (RMS) and Marquardt's percent standard deviation (MPSD)) equations. The Dubinin-Radushkevich isotherm model was best fitted to the experimental data of MBT. Kinetic data were evaluated by pseudo-first-order (PFO), pseudo-second-order (PSO), elovich, intraparticle diffusion and film diffusion models. The adsorption rate was primarily controlled by a pseudo-secondorder rate model with a good correlation $\left(R^{2}>0.99\right)$. The adsorption mechanism process of AR35 dye by MBT mainly involves the adsorption of anions via the electrostatic attraction forces that develop with the increase in the number of positively charged regions at acidic $\mathrm{pH}$ values. The results indicate that MBT is promising for the removal of AR35 dye from water and could be repeatedly used without significant loss of adsorption efficiency.

\section{Introduction}

Concern about water scarcity in some regions around the world is constantly increasing with the continuous pollution of existing waters in different regions. Chemical compounds that cause major pollution in the ecosystem can be listed as dyes (El Nemr 2012a; Rafatullah et al. 2010; Shakoor et al. 2017), heavy metals (Bilal et al. 2013; Chao et al. 2014; El Nemr 2011, 2012b), drugs (Cuerda-Correa et al. 2010), hydrocarbons (El Nemr et al. 2004, 2005, 2013) and pesticides (Ignatowicz 2009; Salem et al. 2013, 2014; El Nemr et al. 2016a, 2016b; Ragab et al. 2016; Asiri et al. 2020; Hassaan and El Nemr 2020). These substances are released into the environment from industrial and hospital wastewater or through domestic sewage (El Nemr 2011, 2016).

In particular, dyes are easily detected in wastewater due to their color. Synthetic dyes are the leading dyes that are widely used in paint, leather, textile and different industries (El Nemr 2012a; Lin et al. 2017). Ecological balance and human health are adversely affected by this pollution as most paints are carcinogenic, toxic and non-biodegradable (Rafatullah et al. 2010; lqbal 2016). The amount of untreated dyestuffs discharged into water bodies, approximately $10-20 \%$, is estimated to average $(0.7-2.0) \times 10^{5}$ tonnes per year (Dawood and Sen 2012). 
Among the synthetic dyes, azo dyes come first because of their features such as having the most color variety, being the largest and being versatile. Carcinogenic compounds are formed as a result of excessive use of these chemicals (Rauf and Ashraf 2009).

There are many techniques for the treatment of dyeing wastewater, and the main ones can be listed as chemical oxidation (Karthikeyan et al. 2012), advanced oxidations (El Nemr et al. 2017, 2018; Hassaan et al. 2017a, b), photo-degradation (Madhusudan et al. 2013; Chang et al. 2016; El Nemr et al. 2019; Helmy et al. 2018, 2021), coagulation/flocculation (Saleh and Gupta 2012), biological treatment (Gupta et al. 2015), electrochemical treatment (Felix et al. 2014) and adsorption treatment (Anastopoulos and Kyzas 2014; Eldeeb et al. 2021; Lin et al. 2016, 2017; Salama et al. 2015). Removal of dyes by adsorption method using activated carbon is one of the most preferred among these techniques due to its high efficiency (El Nemr 2012c). However, the high production and processing cost of commercial activated carbon has led scientists to seek to synthesize cheaper and more effective adsorbent materials (Abdelwahab et al. 2007; Heibati et al. 2015; Song et al. 2015). For this, the trend towards biochar production as a cheaper and environmentally friendly alternative is increasing day by day. Biochars obtained by using biomass and waste materials as starting materials also prevent the waste of scarce resources. Carbonaceous solid materials obtained by gasification or pyrolysis of biomass at temperatures above $350^{\circ} \mathrm{C}$ in a nitrogen atmosphere are defined as biochar (Kołodyńska et al. 2017; Song et al. 2015). Güzel et al. (2017), in their study, found that activities for commercial activated carbon production are generally more expensive than activities for biochar production. In addition to their low cost, biochars also have advantages such as reducing secondary environmental pollution, renewability and creating high value-added adsorbents (Liu et al. 2014). In addition to these, the use of biochar as an adsorbent also reduces the amount of carbon dioxide released into the atmosphere (Ahmad et al. 2014; Abdelhafez and Li 2016). Although biochars have more functional groups on the carbonaceous surface, their surface areas and pore volumes are smaller than activated carbons (Liu et al. 2011; El-Nemr et al. 2022a, b).

In order to improve the practical applications of biochars for the removal of dyestuffs from wastewater, it is possible to further increase the number of functional groups by chemical changes on their surfaces. Modifications such as impregnation with minerals, oxidation, nanoscale formation and reduction of the biochar surface are generally efforts to increase the adsorption capacity of biochar (Wang et al. 2019). Impregnation with mineral elements takes place by adding amino groups to the pores of the adsorbent to increase the functionality of the biochar (Yao et al. 2014). In the surface oxidation method, it is aimed to increase the number of acidic functional groups by using various bases $(\mathrm{KOH}$ or $\mathrm{NaOH})$, acids $\left(\mathrm{H}_{3} \mathrm{PO}_{4}\right.$, $\mathrm{HNO}_{3}$ or $\left.\mathrm{H}_{2} \mathrm{SO}_{4} / \mathrm{HNO}_{3}\right)$ and certain oxidizing reagents $\left(\mathrm{NH}_{3} \cdot \mathrm{H}_{2} \mathrm{O}, \mathrm{O}_{3}, \mathrm{H}_{2} \mathrm{O}_{2}, \mathrm{NaClO}, \mathrm{KMnO}_{4}\right.$ or $\left.\left(\mathrm{NH}_{4}\right)_{2} \mathrm{~S}_{2} \mathrm{O}_{8}\right)$ (Song et al. 201; Jimenez-Cordero et al. 2015; Liatsou et al. 20164; Chang et al. 2018). In nanoscale metals assistance, biochars are loaded with nano metals, increasing the thermal stability, number of adsorption sites, specific surface area and resistance to oxidation of biochar. This increases the affinity of the biochar and helps to remove toxic substances from the water (El-Nemr et al. 2020a, 2020b, 2020c, 2021, 2022a, 2022b; Zhang and Hay 2020). Surface reduction modification occurs by bonding biochars 
with nitrogenous functional groups, especially primary amines, secondary amines, tertiary amines, imidazole and quaternary ammonium. The most commonly used reducing agents can be listed as $\mathrm{Na}_{2} \mathrm{SO}_{3}, \mathrm{H}_{2}, \mathrm{NH}_{3} . \mathrm{H}_{2} \mathrm{O}, \mathrm{FeSO}_{4}$ and aniline (Ma et al. 2014; Sahlabji et al. 2021).

There are many studies in the literature on the adsorption of various pollutants of these adsorbents, which are obtained by obtaining activated carbon from agricultural waste biomass. Coconut husk (Foo and Hameed 2012), olive stone (Yavuz et al. 2010), watermelon peel (El-Nemr et al. 2020), gulmohar (Ponnusami et al. 2009), potato (Gupta et al. 2016; Kyzas et al. 2016), orange peel (El-Nemr et al. 2021a), mandarin peel (Koyuncu et al. 2018; Unugul and Nigiz 2020), wheat straw (Zhang et al. 2012), peanut husk (Song et al. 2011), sesame hull (Feng et al. 2011), coffee bean husks (Baquero et al. 2003), tea waste (Islam et al. 2015), rice straw (Kim et al. 2014), green algae Ulva lactuca (El Nemr et al. 2021b; Shoaib et al. 2021a), red algae Pterocladia capillacea (Shoaib et al. 2021b), sugarcane bagasse (El-Nemr et al.2021c) and Macore fruit (Aboua et al. 2015) are some of these biomass.

Mandarin is one of the temperate climate fruits belonging to a kind of citrus family. According to the data published by the United Nations Food and Agriculture Organization (FAO) in 2021, the annual production of citrus is approximately 80 million tons (FAO 2021). Countries such as China, Turkey, Brazil, Egypt, Spain, Japan, Italy and South Korea are the countries with the highest production. The peels of the mandarins used in fruit juice factories, which are thrown into the environment, constitute approximately 8$14 \%$ of their total weight. These peels are mostly used in solid fuel, fertilizer, cosmetics and animal feed industries (Koyuncu et al. 2018). It produces a large amount of fruit peel as biomass waste due to mandarin consumption (Boluda-Aguilar et al.2010). Organic carbon components such as hemicellulose, cellulose and pectin in its structure allow the production of environmentally friendly biochars from tangerine peels by pyrolysis. Thus, materials with an excellent adsorption capacity are obtained (Dhillon et al. 2004). A comprehensive study on the effect of physicochemical properties of biochars obtained from mandarin peels on the removal of dyestuffs in wastewater has not been published yet. No studies have been conducted on the adsorption performance of biochars obtained by first dehydration with $\mathrm{H}_{2} \mathrm{SO}_{4}$, followed by ozonation in water, and finally, amination with Triethylenetetramine (TETA), using mandarin peel waste materials as a suitable precursor for the removal of Acid Red 35 dye from wastewater. In this study, Mandarin-Biochar- $\mathrm{O}_{3}$-TETA (MBT) produced from mandarin peels, which is a low-cost agricultural waste material, by dehydration process was investigated for its efficiency in Acid Red 35 dye removal from aqueous environment. Parameters such as initial adsorbate concentration, solution $\mathrm{pH}$, contact time between adsorbent and adsorbate and the effect of adsorbent dose were investigated as the removal conditions of Acid Red 35 dye from aqueous solution. Adsorption kinetics and isotherms for the removal of Acid Red 35 dye on MBT adsorbent were investigated to determine the structure and maximum adsorption capacity of the adsorption.

\section{Materials And Methods}

\subsection{Materials and equipment}


Mandarin orange (Citrus reticulata) peels obtained from a local market were used for the production of Mandarin Biochar- $\mathrm{O}_{3}$-TETA (MBT). Sulfuric acid $\left(\mathrm{H}_{2} \mathrm{SO}_{4}, \mathrm{M} . \mathrm{W} .=98.07 \mathrm{~g}, 99 \%\right)$ and Acid Red 35 (AR35) dye $\left(\mathrm{C}_{20} \mathrm{H}_{16} \mathrm{~N}_{4} \mathrm{O}_{9} \mathrm{~S}_{2} \mathrm{Na}_{2}\right)$ were supplied from Sigma Aldrich (Fig. 1). AR35 dye standard stock solution was prepared by dissolving one gram of dye in one litter distilled water.

The Ozonator instrument was used to produce $\mathrm{O}_{3}$ in water from the air and Triethylenetetramine (TETA) was obtained from Sigma Aldrich. Analytic Jena (SPEKOL1300 UV/Visible spectrophotometer with glass cells of $1 \mathrm{~cm}$ optical path, a shaker (JSOS-500) and a pH meter JENCO (6173) were used.

\subsection{Preparation of biochars}

Mandarin orange (Citrus reticulata) peels were properly washed many times with water to eliminate dust and then dried for 48 hours at $105^{\circ} \mathrm{C}$. Crushed and ground-dried Mandarin peels were used in this recipe. For this experiment, $200 \mathrm{~g}$ of crushed mandarin peels were boiled for 3 hours in $1.0 \mathrm{~L}$ of 50 percent $\mathrm{H}_{2} \mathrm{SO}_{4}$ in a refluxed system, after which they were diluted with distilled water, filtered and washed with water until the filtrate became neutral, and then washed with ethanol and dried overnight at $105^{\circ} \mathrm{C}$ and weighed to produce $85 \mathrm{~g}$. The processes of carbonization and sulphonation occurred as a result of this method of preparation. The mandarin biochar produced $(75 \mathrm{~g})$ as a result of this reaction was suspended in $200 \mathrm{ml}$ water and ozonated for $30 \mathrm{~min}$. The ozonated mandarin biochar was filtered, washed with water and dried overnight at $105^{\circ} \mathrm{C}$ and weighed to give $80 \mathrm{~g}$. The oxidized mandarin biochar $(40 \mathrm{~g})$ was then heated in a $120 \mathrm{~mL}$ solution of TETA for 3 hours in a refluxed system. The reaction mixture was filtered and rinsed twice with distilled water, ethanol and dried at $70^{\circ} \mathrm{C}$ overnight to give $47 \mathrm{~g}$. TETA was added to the product's label, which read Mandarin-Biochar- $\mathrm{O}_{3}$-TETA (MBT).

\subsection{Batch adsorption experimental}

A stock solution of AR35 dye (1000 $\left.\mathrm{mg} \mathrm{L}^{-1}\right)$ was obtained by dissolving $1.0 \mathrm{~g}$ of AR35 dye in $1 \mathrm{~L}$ of pure water, and this solution was diluted to the desired concentrations for the calibration standard curve and adsorption tests. The adsorption capabilities, thermodynamic and kinetic characteristics of MBT were determined using batch adsorption studies. A series of Erlenmeyer flasks $(300 \mathrm{~mL})$ was shaken at 200 rpm for a specified duration with $100 \mathrm{~mL}$ of various concentrations of AR35 dye solution and varying volumes of MBT. With $0.1 \mathrm{M} \mathrm{HCl}$ or $0.1 \mathrm{M} \mathrm{NaOH}$, the $\mathrm{pH}$ of the sample was changed to the appropriate levels. Concentration measurement of AR35 dye was performed by taking $1 \mathrm{~mL}$ sample from the solution in the Erlenmeyer flask and separating from the adsorbent, at various intervals and equilibrium. The concentration of AR35 dye was measured using spectrophotometry $\lambda_{\max }=505 \mathrm{~nm}$. The equilibrium adsorption capacities $\left(q_{\mathrm{e}}\right)$ were estimated using equation (1):

$$
q_{t}=\frac{\left(C_{0}-C_{t}\right)}{W} \times V
$$


Where the adsorption capacity $\left(q_{\mathrm{t}}\right)(\mathrm{mg}$ adsorbate/g adsorbent) is the adsorbent's ability to remove AR35 dye from a solution at a certain time. $C_{0}(\mathrm{mg} / \mathrm{L})$ is the initial concentration of AR35 dye; $C_{\mathrm{t}}(\mathrm{mg} / \mathrm{L})$ is the residual concentration of the AR35 dye after the adsorption process had been completed for a given time. The following equation can be used to calculate the elimination \% of AR35 dye from an aqueous solution (2).

$$
\operatorname{Removal}(\%)=\frac{\left(C_{0}-C_{t}\right)}{C_{0}} \times 100
$$

The influence of pH on AR35 dye adsorption was examined by mixing $0.1 \mathrm{~g}$ of the adsorbent with $100 \mathrm{~mL}$ of AR35 dye solution of a concentration of $100 \mathrm{mg} / \mathrm{L}$ for MBT $(0.1 \mathrm{~g})$ with initial $\mathrm{pH}$ values varying between 1.5 and $12.0 .1 \mathrm{M} \mathrm{HCl}$ and $0.1 \mathrm{M} \mathrm{NaOH}$ solutions were used to modify the pH levels. At $25^{\circ} \mathrm{C}$, the suspensions were agitated at $200 \mathrm{rpm}$ for $180 \mathrm{~min}$ before being sampled for AR35 dye measurement. For the isotherm investigation, $100 \mathrm{~mL}$ of AR35 dye solutions were mixed at $200 \mathrm{rpm}$ for 3 hours at $25^{\circ} \mathrm{C}$ with varying initial concentrations of AR35 dye solutions (100-400 mg/L) and various amounts of MBT (50 to $250 \mathrm{mg}$ ). At $25^{\circ} \mathrm{C}$, the effect of adsorbent dosage and contact time on AR35 dye removal was investigated by shaking $100 \mathrm{~mL}$ of initial AR35 dye concentration for MBT with varied adsorbent dosages of $(50,100,150,200$ and $250 \mathrm{mg})$ at different interval times.

\subsection{MBT characterization}

The adsorption-desorption isotherm of $\mathrm{N}_{2}$ on MBT was calculated at the boiling point of nitrogen gas. The surface area and pore analyzer (BELSORP - Mini II, BEL Japan, Inc.) was used to assess the BET surface area $\left(S_{B E T}\right)$ of the biochar using nitrogen adsorption at $77 \mathrm{~K}$ (Gregg and Sing 1982; Rouquerolet al. 1999). The BET plot was used to calculate surface area $\left(S_{\mathrm{BET}}\right)\left(\mathrm{m}^{2} / \mathrm{g}\right)$, monolayer volume $\left(V_{\mathrm{m}}\right)\left(\mathrm{cm}^{3}\right.$ $\left.(\mathrm{STP}) \mathrm{g}^{-1}\right)$, total pore volume $\left(p / p_{0}\right)\left(\mathrm{cm}^{3} / \mathrm{g}\right)$, mean pore diameter $(\mathrm{nm})$ and energy constant $(C)$ for the isotherm. The following equation was used to compute the average pore radius (3).

$$
r(n m)=\frac{2 V_{T}\left(m L g^{-1}\right)}{a_{s, B E T}\left(m^{2} g^{-1}\right)} \times 1000
$$

3

To determine the mesopore surface area $\left(S_{\text {mes }}\right)$, micropore surface area $\left(S_{\mathrm{mi}}\right)$, mesopore volume $\left(V_{\text {mes }}\right)$ and micropore volume $\left(V_{\text {mic }}\right)$ of MBCT, Barrett-Joyner-Halenda $(B J H)$ method was used by using BELSORP analysis program software. The BJH method (Barrett et al. 1951) is used to compute the pore size distribution from the desorption isotherm. 
The surface morphology of the MBCT sample was investigated using a Scanning Electron Microscope (SEM) (QUANTA 250) in conjunction with an Energy Dispersive X-ray Spectrometer (EDX) for elemental analysis.

The functional groups on the MBT surface were investigated using Fourier Transform Infrared (FTIR) spectroscopy (VERTEX70) and ATR unit model V-100.

Thermal analyzes were carried out using the SDT650-Simultaneous Thermal Analyzer device at a temperature range of $25^{\circ} \mathrm{C}$ to $1000^{\circ} \mathrm{C}$, at a temperature increase rate of $10^{\circ} \mathrm{C} / \mathrm{min}$.

\section{Results And Discussions}

\subsection{The characteristics of MBT}

Fourier Transform Infrared Spectroscopy (FT-IR) was used to analyze the generated biochar sample in order to detect changes in the functional groups of the sample. The raw Mandarin peels and MBT FT-IR spectra are shown in Fig. 2. Specifically, the strong band at $3252.8 \mathrm{~cm}^{-1}$ corresponds to the $\mathrm{O}-\mathrm{H}$ stretching vibration that existed in Mandarin peels, whereas the broad adsorption peak about 3234.5 $\mathrm{cm}^{-1}$ is indicative of the presence of the $-\mathrm{OH}$ group of glucose and the -NH of TETA in the MBT (Fig. 2). The presence of this new band suggested that the amino group had been introduced into the biochar surface as a result of the reaction with TETA. According to this theory, the $-\mathrm{CH}_{2}$ stretching vibration that existed in Mandarin peels and the MBT existed at 2921.6-2854.1 cm-1 and 299.4-2853.0 $\mathrm{cm}^{-1}$, respectively. There is no adsorption peak about $1710.9 \mathrm{~cm}^{-1}$, demonstrating that the $\mathrm{C}=0$ stretching of the carboxyl group that appeared in Mandarin peels has disappeared in the prepared biochar MBT (Fig. 2). The presence of the band at $1646 \mathrm{~cm}^{-1}$ in Mandarin peels and at $1635.95 \mathrm{~cm}^{-1}$ in MBT indicated the presence of amide groups in both materials. In MBT, the N-H stretching vibration in TETA was observed at a frequency of $1560.4 \mathrm{~cm}^{-1}$, indicating that TETA modification may have increased the $\mathrm{N}-\mathrm{H}$ functional group of MBT. The adsorption peak at $1419.3 \mathrm{~cm}^{-1}$ indicates the presence of the C-O functional group in Mandarin peels, whereas the strong adsorption peaks at 1440.9 and $1363.4 \mathrm{~cm}^{-1}$ were attributable to the stretching vibration of the $-\mathrm{N}=\mathrm{C}=\mathrm{O}$ group in MBT. The appearance of this new peak on the MBT surface indicates that amino groups were successfully introduced following the treatment with TETA. The band at $1034.6 \mathrm{~cm}^{-1}$ represents that the $\mathrm{C}-\mathrm{O}-\mathrm{H}$ functional group existed in MBT while it is strong in Mandarin peels at $1090.2 \mathrm{~cm}^{-1}$. Furthermore, it seems there was an obvious difference between Mandarin peels and MBT in the peak strength of $1029-1093 \mathrm{~cm}^{-1}$, indicating TETA modification could affect the $\mathrm{C}-\mathrm{O}-\mathrm{H}$ functional group of MBT (Fig. 2). Also, the $\mathrm{OH}$ vibration that appeared at $609.1 \mathrm{~cm}^{-1}$ in Mandarin peels was completely disappeared on the surface of the MBT.

The textural properties were calculated by the (BET) and (BJH) methods including the BET specific surface area, total pore volume, mean pore diameter, mono layer volume, mesopore area, mesopore volume and mesopore distribution peak for the MBT and are presented in Fig. 3. As shown in Fig. 3, the 
BET-specific surface area of MBT $\left(5.65 \mathrm{~m}^{2} / \mathrm{g}\right)$ and the mono layer volume value of MBT was $1.3419 \mathrm{~cm}^{3}$ (STP) $/ \mathrm{g}$. The total pore volume value of MBCT was $0.0175 \mathrm{~cm}^{3} / \mathrm{g}$ and the mean pore diameter of MBT biochars was $11.74 \mathrm{~nm}$ (mesopores). The meso surface area of MBT was $6.18 \mathrm{~m}^{2} / \mathrm{g}$ and the meso pore volume value of MBT was $0.018 \mathrm{~cm}^{3} / \mathrm{g}$. The meso pore distribution peak value of MBT was $1.22 \mathrm{~nm}$. It was reported that the pores in the prepared modified biochar may be blocked by the TETA reaction (ElNemr et al. 2020a, 2020b).

SEM micrographs of the MBT were examined. Fig. 4 shows the surface morphology of MBT and according to the image, most of the pores and caves had been blocked by the TETA decoration (El-Nemr et al. 2020a, 2020b).

The EDX analysis was carried out for the MBT for its chemical composition. The chemical composition of MBT was reported in Fig. 5, which showed the EDX analysis of MBT proved the presence of $16.05 \%$ sample weight for nitrogen element. The major elements in the MBT were carbon (57.24\%) followed by oxygen atoms (26.34\%) and nitrogen (16.05\%). A small amount of sulfur atom (0.37\%) was recorded as a result of the dehydration step with $\mathrm{H}_{2} \mathrm{SO}_{4}$.

The thermo gravimetric profile of the raw materials Mandarin peels and MBT as a function of temperature is shown in Fig. 6. The decomposition of the raw material Mandarin peels occurs in four processes, whereas the decomposition of the MBT occurs in two steps, as shown in Fig. 6 . The first process, which takes place at temperatures between 50 and $150^{\circ} \mathrm{C}$, involves the loss of surface-bound water and moisture in the sample, with weight losses of 4.5 and $8.80 \%$ for raw material Mandarin peels and MBT, respectively. The second weight-loss stage, with Mandarin, peels losing $25.27 \%$ at $150-300^{\circ} \mathrm{C}$ and MBT losing $45.83 \%$ at $150-1000^{\circ} \mathrm{C}$, respectively. At $300-385^{\circ} \mathrm{C}$, the Mandarin peel loses about $25.04 \%$ of its weight in the third weight-loss stage followed by losing $14.23 \%$ of its weight in the fourth and final weight-loss stage between 385 and $1000^{\circ} \mathrm{C}$ (El-Nemr et al. 2020a, 2020b).

Differential thermal analysis (DTA) can be used solely for identification purposes, although it is most commonly employed for phase diagram determination, heat change measurements, and decomposition in various atmospheres (Fig. 6). The DTA curve of the Mandarin-peels sample exhibits three peaks at a temperature of flow $T_{f}\left(80.19,243.82\right.$ and $\left.342.32^{\circ} \mathrm{C}\right)$. However, the pyrolysis of the Mandarin peels shows three well-resolved degradation peaks. The DTA analysis of the MBT sample showed manly two wellresolved degradation peaks at a temperature of flow $T_{f}\left(78.91,418.81^{\circ} \mathrm{C}\right)$, and onset points at 58.1 , and $212.61^{\circ} \mathrm{C}$. This proved that the stability of the MBT sample increased by surface decoration with ozonation and TETA than Mandarin peels (El-Nemr et al. 2020a, 2020b).

Thermal transitions can be used to compare materials using differential scanning calorimetry (DSC). The DSC analyses of Mandarin peels and MBT are shown in Fig. 7. Both of the samples had crystallization temperatures $T_{\mathrm{C}}$ below $100^{\circ} \mathrm{C}$ ( 88.15 and $92.51^{\circ} \mathrm{C}$, respectively), which can be attributed to water molecule crystallization. The other two exothermic phase transitions were reported for the DSC analysis of Mandarin peels at 263.73 and $347.82^{\circ} \mathrm{C}$. The other crystallization temperature $T_{\mathrm{C}}$ of raw Mandarin 
peels was found to be at 482.19 and $807.41^{\circ} \mathrm{C}$ using DSC. Two other phase transitions were reported for the DSC of MBCT at $393.04^{\circ} \mathrm{C}$ as endothermic and at 728.57 as exothermic phase transition (El-Nemr et al. 2020a, 2020b).

Figure 8 shows the XRD of the MBT. The broad peak in the region of $2 \theta=10-30$ and $40^{\circ}-50^{\circ}$ is indexed as $\mathrm{C}$ (002) and (101) planes diffraction peaks indicating an amorphous carbon structure with randomly oriented aromatic sheets (Yeboah et al. 2020). There is small peak around $2 \theta=43.669$ indicated that the adsorbent had an amorphous structure including cellulose, hemicellulose and lignin (Hassaan et al. 2021; Yıldırım and Bayrak 2021) or may also correspond to the presence of some inorganic components in MBCT (Hassaan et al. 2021; Slaný et al. 2019).

\subsection{Adsorption of Acid Red 35 dye on Mandarin-Biochar 3.2.1 Effect of $\mathrm{pH}$}

Textile industry wastewater has very different $\mathrm{pH}$ values from each other. The adsorption process is highly affected by the solution $\mathrm{pH}$, which affects the carboxyl, hydroxyl and amino groups on the biochar surface. Determination of the amount of Acid Red 35 (AR35) dye adsorbed at equilibrium $\left(q_{e}\right)$ and removal of these dyes; carried out at room temperature $\left(25 \pm 2^{\circ} \mathrm{C}\right)$, at an initial AR35 dye concentration of $100 \mathrm{mg} \mathrm{L}^{-1}$ and using $0.5 \mathrm{~g} \cdot \mathrm{L}^{-1} \mathrm{MBT}$ as adsorbent. The adsorption of AR35 dye was studied for 2 hours at $\mathrm{pH}$ values between 1.5 and 12 and $\mathrm{pH}$ changes are shown in Fig. 9. For the removal of AR35 dye using MBT, it is seen in Fig. 9a that the highest AR35 dyes removal (97.5\%) occurred at pH 1.5. In the study conducted for the removal of AR35 dye, decreasing the $\mathrm{pH}$ value continuously from 1.5 to 9 caused the adsorption rate to decrease from $97.5-2.6 \%$. This decrease in the percentage of adsorption removal occurred sharply from $\mathrm{pH} 1.5$ to $\mathrm{pH} 4$, but slightly from $\mathrm{pH} 4$ to $\mathrm{pH}$ 9. With the increase of the $\mathrm{pH}$ value from 9 to 12, the adsorption rate increased slightly and reached around $16.2 \%$. Considering the studies on the removal of azo dyes, Khaled et al. (2009) found that the adsorption efficiency decreased from 98.1$11.1 \%$ by increasing the $\mathrm{pH}$ of the solution from 1.5 to $11.1 \%$ in their study on the removal of Direct Yellow 12 dye. In addition, Aboua et al. (2015) reported that the adsorption efficiency decreased from 98$56 \%$ by increasing the $\mathrm{pH}$ value from 2 to 11 in the removal of Methyl Orange dye. Song et al. (2015) reported that the adsorption capacity decreased sharply by increasing the $\mathrm{pH}$ value from 2 to 4 in the removal of Sunset Yellow dye. It was determined that the optimum pH value for the removal of AR35 dye for MBT was 1.5 .

The presence of excess $\mathrm{OH}^{-}$ions in a high solution $\mathrm{pH}$ (alkaline environment) reduces the adsorption efficiency as they compete with the anions of AR35 dye, an anionic dye, for adsorption sites. In addition, MBT adsorbent wants to adsorb high concentration and high mobility $\mathrm{OH}^{-}$ions more than dye anions. What facilitates the adsorption of anions is the electrostatic attraction forces that develop with the increase in the number of positively charged regions at acidic $\mathrm{pH}$ values. The very high adsorption efficiency in the strongly acidic region with a pH of 1.5 can be explained as follows: In fact, there are negatively charged surface regions on MBT and these regions do not support the adsorption of anionic 
AR35 dye molecules due to electrostatic repulsion. This is due to the hydrophobic nature of biochar. When the MBT adsorbent is immersed in water, hydrogens attach to the surface of the carbon and charge it positively. Therefore, adsorption becomes possible by creating attractive forces between the positively charged MBT and the negatively charged AR35 dye.

Determining the $\mathrm{pH}$ value at which the adsorbent surface has net electrical neutrality is possible by determining the zero charge point $\left(\mathrm{pH}_{\mathrm{PZC}}\right.$ ) (El Qada et al. 2006). To find out pHpzc, the experiments were conducted at different $\mathrm{pH}$ ranges from 2 to 12, by adding $50 \mathrm{mg}$ of adsorbent to $100 \mathrm{~mL}$ of solution and agitated on a magnetic stirrer. The $\mathrm{pH}$ of the solution was measured after $25 \mathrm{~min}$. As shown in Fig. 9b, the

$\mathrm{pH}_{\mathrm{PZC}}$ of MBT was determined to be 9.64. At the solution $\mathrm{pH}>\mathrm{pH}_{\mathrm{PZC}}$, the MBT surface is negatively charged and electrostatic repulsive forces are formed between it and negatively charged anionic dyes. However, in our study, when the pH value increased from 9 to 12, there was a slight increase in AR35 dye removal.

\subsubsection{Effect of contact time}

Contact time is an important parameter for MBT adsorbent and AR35 dye to provide the necessary interaction. For this reason, the effect of contact time was investigated using MBT at pH 1.5, at an AR35 dye initial concentration ranging from 100 to $400 \mathrm{mg} \cdot \mathrm{L}^{-1}$. It can be seen from Fig. 10 that the adsorption process takes place very rapidly in the first 5 minutes, and it gradually increases after this minute. Fig. 10 shows that approximately $17-55 \%$ of the adsorption of AR35 dye takes place in the first 15-30 minutes. The removal of the AR35 dye increased continuously with the increase of the contact time, and after 3 hours, depending on the initial concentration $\left(100,150,200,300\right.$ and $\left.400 \mathrm{mg} \cdot \mathrm{L}^{-1}\right)$ of the AR35 dye, the removal was $84 \%, 67 \%, 42 \%, 31 \%$ and $25 \%$, respectively.

In the removal of AR35 dye with a low initial concentration on the MBT adsorbent, since the dye concentration of the empty active sites is low, most of these ions will be able to hold on to the MBT adsorbent and there will be high removal. On the other hand, in the removal of AR35 dye with a high initial concentration on MBT adsorbent, the removal percentage will remain low, since the empty active sites cannot adsorb other dyes after they are filled with a certain amount of AR35 dyes. El Nemr et al. (2020c) observed a similar trend in their study on the removal of Acid Yellow 11 dye.

\subsubsection{Effect of initial AR35 dye concentration}

The initial concentration of the adsorbed substance is an important parameter in the adsorption process to examine the effect of the initial AR35 dye concentration on the adsorption capacity at equilibrium $\left(q_{e}\right)$. In order to determine the effect of MBT dosage on adsorption capacity at equilibrium $\left(q_{e}\right)$, the adsorbent concentration $\left(0.5,1.0,1.5,2.0\right.$ and $\left.2.5 \mathrm{~g} \mathrm{~L}^{-1}\right)$ and the initial $\operatorname{AR3}$ dye concentration $(100,150,200,300$ and $\left.400 \mathrm{mg} \cdot \mathrm{L}^{-1}\right)$ was studied at room temperature $\left(25 \pm 2^{\circ} \mathrm{C}\right)$ at a $\mathrm{pH}$ of 1.5 . Fig. 11 shows that the adsorbed amount of AR35 dye at the same initial concentration of AR35 dye increases at equilibrium $\left(q_{e}\right)$ with the decrease in MBT doses. The adsorption capacities at equilibrium $\left(q_{e}\right)$ in AR35 dye removal were determined by using MBT adsorbents at different doses $\left(0.5-2.5 \mathrm{~g} \mathrm{~L}^{-1}\right)$ as shown in Fig. 11. These values 
range from 195.3 to $465.7,98.2$ to $375.7,65.6$ to $261.8,49.3$ to 197.2 and 39.5 to $158.5 \mathrm{mg} \mathrm{g}^{-1}$ for initial AR35 dye concentrations $\left(100,150,200,300\right.$ and $\left.400 \mathrm{mg} \cdot \mathrm{L}^{-1}\right)$, respectively. As can be seen from Fig. 11, the adsorption capacity $\left(q_{e}\right)$ of AR35 dye on MBT at equilibrium is higher in solutions with higher initial AR35 dye concentration. It was observed that it decreased as the adsorbent dose increased. Therefore it indicates that the adsorption of AR35 dye from its aqueous solution was dependent on its initial concentration. Khaled et al. (2009) observed a similar trend in their study on the removal of Direct Yellow 12 dye.

In the adsorption process of AR35 dye on MBT adsorbent, AR35 dye molecules first encounter the boundary layer effect, then diffuse from the boundary layer film to the surface of the MBT adsorbent and finally are attached by the porous structure of the adsorbent.

\subsubsection{Effect of adsorbent dosage on AR35 dye adsorption}

Experimental conditions to examine the effect of adsorbent dosage on AR35 dye removal, initial concentration of AR35 dye (100 - $\left.400 \mathrm{mg} \cdot \mathrm{L}^{-1}\right)$, MBT adsorbent dosages $\left(0.5-2.5 \mathrm{~g} \cdot \mathrm{L}^{-1}\right)$, solution temperature $\left(25 \pm 2^{\circ} \mathrm{C}\right)$, the adsorption time (180 minutes) and solution $\mathrm{pH}$ were adjusted to 1.5 , and the results are shown in Fig. 12. Experimental results show that with the increase of MBT adsorbent dosage, the percentage of AR35 dye removal (\%) increases slightly (in the range of 97.5-99\%) (Fig. 12a,b), whereas the amount of AR35 dye adsorbed at equilibrium $\left(q_{e}\right)$ decreases with the increase of MBT adsorbent dosage (Fig. 12c). The reason for the release in the case where the adsorbent dosage is 0.5 $\mathrm{g} \cdot \mathrm{L}^{-1}$ and the initial AR35 dye concentration is $300-400 \mathrm{mg} \cdot \mathrm{L}^{-1}$ is the rapid filling of the active sites on the MBT surface in the presence of highly concentrated dye molecules. As a result, dye removal was limited to around $58-71 \%$.

The amount of AR35 dye adsorbed at equilibrium $\left(q_{e}\right)$ decreases from 195.3 to $39.5,294.0$ to $59.5,390.2$ to $78.0,428.6$ to 119.0 and 465.7 to $158.5, \mathrm{mg} \cdot \mathrm{g}^{-1}$ with increasing of the amount of MBT adsorbent from 0.5 to $2.5 \mathrm{~g} \cdot \mathrm{L}^{-1}$ for initial AR35 dye concentrations $100,150,200,300$ and $400 \mathrm{mg} \cdot \mathrm{L}^{-1}$, respectively. It was determined that the maximum removal percentage of AR35 dye and the minimum adsorption amount at equilibrium $\left(q_{e}\right)$ were obtained by using $2.5 \mathrm{~g} \cdot \mathrm{L}^{-1} \mathrm{MBT}$ dose.

\subsection{Adsorption isotherms}

In order to explain the state of the adsorbate molecules dispersed between the solid-liquid phases, the correlation between the mass of the adsorbent $\left(q_{e}\right.$ in $\left.\mathrm{mg} \cdot \mathrm{g}^{-1}\right)$ at the equilibrium time and the adsorbate concentration ( $C$ in $\mathrm{mg} \cdot \mathrm{L}^{-1}$ ) is used, which is called the adsorption isotherm (El Nemr et al. 2010; Fu et al. 2015). Isotherm data are used to determine the optimum amount of adsorbent to be used and to determine the molecular fraction of adsorbate distributed in equilibrium $\left(q_{e}\right)$ between solid-liquid phases. In this study, the interaction between MBT adsorbent and AR35 dye was investigated using Langmuir, Freundlich, Tempkin and Dubinin-Radushkevich isotherm models (El Nemr et al. 2010). 
The values obtained as a result of the adsorption of AR35 dye on MBT adsorbent are shown in Table 1, where the constants of the Langmuir isotherm model are the affinity of the adsorption sites $\left(K_{L}\right)$ and the saturated monolayer adsorption capacity $\left(Q_{m}\right)$. In the removal of AR35 dye, MBT adsorbent with $0.5 \mathrm{~g} \cdot \mathrm{L}^{-1}$ dose showed a high correlation coefficient $\left(R^{2} \geq 0.998\right)$ in the linear form of the Langmuir model, and the maximum monolayer capacity $\left(Q_{m}\right)$ was calculated as $476.19 \mathrm{mg} \cdot \mathrm{g}^{-1}$. The intersection point and slope of the $C_{e} / q_{e}$ versus $C_{e}$ plot shown in Fig. 13a gave the $1 / Q_{m} K_{L}$ and $1 / Q_{m}$ values of the Langmuir model, respectively. High correlation coefficient $\left(\mathrm{R}^{2} \geq 0.998\right)$ and equilibrium adsorption constants $\left(K_{L}\right)$ ranging from 0.06 to $0.84 \mathrm{~L} \cdot \mathrm{mg}^{-1}$ can be cited as strong evidence of the adsorption of AR35 dye on MBT. Applicability of AR35 dye for adsorbing on MBT adsorbent appears to be possible according to the Langmuir isotherm model. Therefore, it was concluded that AR35 dye was adsorbed on the MBT adsorbent surface as a single layer.

Another model applied for the removal of AR35 dye by MBT adsorbent is the Freundlich isotherm model. The Freundlich isotherm model was applied to determine how effective MBT adsorbent was in the removal of AR35 dye. Linear fitting parameters obtained from the Freundlich isotherm model, which constitutes the adsorption process as a heterogeneous phenomenon, are given in Table 1. The intersection point and slope of the $\log \left(q_{e}\right)$ versus $\log \left(C_{e}\right)$ plot shown in Fig. $13 \mathrm{~b}$ give the $\log K_{F}$ and $1 / n_{F}$ values of the Freundlich isotherm model, respectively.

The value of $K_{F}\left(\mathrm{~L} \cdot \mathrm{g}^{-1}\right)$, which represents the binding energy, expresses the amount of AR35 dye adsorbed on the adsorbent for unit equilibrium concentration and is one of the Freundlich constants as a distribution or adsorption coefficient. The higher the $K_{F}$ value, the higher the adsorption capacity of the adsorbent. In addition, a value of $1 / n$ less than 1 means that the adsorbate is easily adsorbed by the adsorbent. Therefore, when $1 / n$ is less than 1 , removal of AR35 dye by MBT adsorbent is a physical process. If the $1 / n$ values in Table 1 are examined, it can be concluded that the adsorption of AR35 dye on the MBT adsorbent is appropriate since all values are less than one. In addition, the $n_{F}$ value expresses the degree of nonlinearity between the solution concentration and the adsorption process, and when this value is greater than 1, the adsorption of AR35 dye on the MBT adsorbent takes place physically.

The variation in $\log \left(q_{e}\right)$ as a function of $\log \left(C_{e}\right)$ successfully defines the Freundlich isotherm correlation coefficient values (Fig. 13b). The better adsorbability of AR35 dye to MBT adsorbent depends on the high $Q_{m}$ value, which is $350.16 \mathrm{mg} \cdot \mathrm{g}^{-1}$ and belongs to the adsorbent with a $0.5 \mathrm{~g} \cdot \mathrm{L}^{-1}$ concentration as given in Table 1. Freundlich correlation coefficient $\left(R^{2} \geq 0.965\right)$ for MBT adsorbent was lower than Langmuir's correlation coefficient.

The Temkin Model, which explains the effects of indirect adsorbent/adsorbate interactions on the adsorption process, is another isotherm model and has been applied to experimental data. The Temkin isotherm model takes into account the heat exchange that occurs during the adsorbate's adsorption on the adsorbent surface. As a result of the adsorption process, it is assumed that the heat of adsorption of all molecules in the layer decreases linearly with time. Temkin isotherm parameters $\left(A_{T}\right.$ and $\left.B_{T}\right)$ of the 
adsorption of AR35 dye by MBT adsorbent are calculated from the linear relationship between $q_{e}$ and $\ln C_{e}$ as seen in Fig. 13c. The slope of the graph is used to calculate the equilibrium bonding constant $A_{T}$ $\left(\mathrm{g} \cdot \mathrm{L}^{-1}\right)$, and the intercept is used to calculate the $B_{T}$, which expresses the adsorption heat coefficient. Table 1 gives the calculated Temkin model constants. The Temkin isotherm correlation coefficient $\left(\mathrm{R}^{2} \geq\right.$ 0.990) obtained in the removal of AR35 dye from the adsorbent with $1.5 \mathrm{~g} \cdot \mathrm{L}^{-1}$ of MBT dosage is quite high, and it is concluded that the model is suitable for examining the temperature changes in the adsorption process. The very low heat of sorption caused the removal of the AR35 dye by physisorption and the very weak ionic interaction between the adsorbent and the adsorbate. The adsorbent-adsorbate interaction is related to the heat of adsorption $\left(B_{T}\right)$, and the coating of the AR35 dye on the MBT adsorbent is affected by this heat. If Table 1 is examined, this value increased continuously with the increase in the dosage of MBT from 0.5 to $1.5 \mathrm{~g} \cdot \mathrm{L}^{-1}$, while after this dosage it decreased to $2.5 \mathrm{~g} \cdot \mathrm{L}^{-1}$.

The Dubinin-Radushkevich (D-R) isotherm model is the model in which the equilibrium data are applied to determine whether the adsorption of AR35 dye on the MBT adsorbent occurs chemically or physically. In this model, considering the Polanyi potential theory, it is assumed that the adsorption process continues until the pores are filled. The correlation coefficients and D-R isotherm constants obtained in the adsorption of AR35 dye on the MBT surface at different dosages are given in Table 1. The apparent energy $E$ value is used to estimate the type of adsorption. It is possible to determine the adsorption type according to the value of the apparent energy $(E)\left(E<8 \mathrm{~kJ} \mathrm{~mol}^{-1}\right.$ "physical adsorption", $8 \mathrm{~kJ} \mathrm{~mol}^{-1}<E<$ $16 \mathrm{~kJ} \mathrm{~mol}^{-1}$ "ion exchange", $E>16 \mathrm{~kJ} \mathrm{~mol}^{-1}$ "chemical adsorption") (Chowdhury et al. 2011; Mobasherpour et al. 2012). When the estimated binding energy $(E)$ values in Table 1 are examined, it is seen that all MBT adsorbent dosages are greater than $16 \mathrm{~kJ} \mathrm{~mol}^{-1}$, and in this case, it is concluded that the adsorption of AR35 dye on MBT adsorbent is by chemical adsorption. The correlation coefficient $\left(R^{2}\right)$ values obtained for the AR35 dye removal of MBT adsorbent at different dosages in the D-R model range between 0.687 and 0.980 , and it seems to be more compatible with the experimental data at most adsorbent dosages compared to the Langmuir isotherm model (Fig. 13d; Table 1).

In addition to the isotherm models mentioned so far, the experimental data is also adapted to the Jovanovic isotherm model. In addition to the assumptions of the Langmuir isotherm model, this model assumes that there may be some mechanical contact between adsorbing and desorbing molecules (Salarirad and Behnamfard 2011). The Jovanovic constants obtained from the $C_{e}$ versus $\ln \left(q_{e}\right)$ plot shown in Fig. 13e are summarized in Table 1. The fact that the $R^{2}$ values are quite low (except for the $2 \mathrm{~g}$ $\mathrm{L}^{-1}$ concentration) shows that it is not appropriate to adapt the experimental data to this model. A comparison of four different isotherm models applied with experimental data is given in Fig. $13 \mathrm{f}$. 
Table 1

Isotherm study data of adsorption of AR35 dye onto MBT adsorbent (Initial AR35 dye concentration = $\left(100-400 \mathrm{mg} \cdot \mathrm{L}^{-1}\right)$, adsorbent doses $=\left(0.5-2.5 \mathrm{~g} \cdot \mathrm{L}^{-1}\right)$, temperature $=\left(25 \pm 2^{\circ} \mathrm{C}\right)$ ).

Isotherm Model

Parameters

MBT adsorbent doses $\left(\mathrm{g} \cdot \mathrm{L}^{-1}\right)$

\begin{tabular}{|c|c|c|c|c|c|c|}
\hline & & $0.5 \quad 1.0$ & 1. & 2.0 & 2. & \\
\hline \multirow[t]{3}{*}{ Langmuir } & $Q_{m}\left(\mathrm{mg} \mathrm{g}^{-1}\right)$ & 476.19 & 357.14 & 370.37 & 357.14 & 370.37 \\
\hline & $K_{L} \times 10^{3}$ & 350.00 & 222.22 & 60.11 & 100.00 & 843.75 \\
\hline & $\mathrm{R}^{2}$ & 0.998 & 0.976 & 0.428 & - & 0.516 \\
\hline \multirow[t]{4}{*}{ Freundlich } & $1 / n$ & 0.14 & 0.45 & 0.87 & 1.00 & 0.61 \\
\hline & $Q m\left(\mathrm{mg} \mathrm{g}^{-1}\right)$ & 350.16 & 220.31 & 151.47 & 112.89 & 85.73 \\
\hline & $\begin{array}{l}K_{F}\left(m g^{1-1 / n} L^{1 / n}\right. \\
\left.g^{-1}\right)\end{array}$ & 234.26 & 103.85 & 53.17 & 35.85 & 48.89 \\
\hline & $\mathrm{R}^{2}$ & 0.641 & 0.750 & 0.932 & 0.965 & 0.485 \\
\hline \multirow[t]{3}{*}{ Temkin } & $A_{T}$ & 147.56 & 2.12 & 1.11 & 1.04 & 2.96 \\
\hline & $B_{T}$ & 46.59 & 101.33 & 128.30 & 105.32 & 47.59 \\
\hline & $\mathrm{R}^{2}$ & 0.727 & 0.858 & 0.990 & 0.915 & 0.391 \\
\hline \multirow[t]{4}{*}{$\begin{array}{l}\text { Dubinin- } \\
\text { Radushkevich }\end{array}$} & $Q_{m}\left(\mathrm{~mol} \mathrm{~kg}^{-1}\right)$ & 461.00 & 371.04 & 271.73 & 179.97 & 136.73 \\
\hline & $\begin{array}{l}K \times 10^{6}(\mathrm{~mol} \\
\left.\mathrm{kJ}^{-1}\right)^{2}\end{array}$ & 0.001 & 1.10 & 1.00 & 0.80 & 0.50 \\
\hline & $E\left(\mathrm{~kJ} \mathrm{~mol}^{-1}\right)$ & 22360.68 & 674.20 & 707.11 & 790.57 & 1000.00 \\
\hline & $\mathrm{R}^{2}$ & 0.967 & 0.980 & 0.975 & 0.870 & 0.687 \\
\hline \multirow[t]{3}{*}{ Jovanovic } & $Q_{m}\left(\mathrm{mg} \mathrm{g}^{-1}\right)$ & 284.01 & 148.95 & 64.084 & 36.165 & 48.371 \\
\hline & $K_{j}\left(\mathrm{mg} \mathrm{g}^{-1}\right)$ & -0.0034 & -0.0408 & -0.2166 & -0.326 & -0.193 \\
\hline & $\mathrm{R}^{2}$ & 0.486 & 0.534 & 0.813 & 0.921 & 0.310 \\
\hline
\end{tabular}

\subsection{Error function studies for Best-fit isotherm model}

Using Langmuir, Freundlich, Tempkin and Dubinin-Radushkevich isotherm models, correlation coefficients $\left(R^{2}\right)$ were compared to determine the most suitable model for the adsorption of AR35 dye to MBT adsorbent, to the experimental equilibrium data. Another way to determine the optimal isotherm model for 
experimental data is to compare several different error function values. Error functions such as average percent errors (APE), Chi-square error $\left(\mathrm{X}^{2}\right)$, hybrid error function (HYBRID), Marquardt's percent standard deviation (MPSD), sum of absolute errors (EABS) and root mean square errors (RMS) are the main functions used to determine the error distribution between the equilibrium values and the estimated isotherm models (El Nemr et al. 2010). The comparison of the error functions, which express the similarity between the experimental data of the MBT adsorbent and the values calculated using the theoretical isotherms, is given in Table 2. When Table 2 is examined, it is clear that the most suitable isotherm model belongs to the Temkin model, which has the lowest (APE), ( $\mathrm{X}^{2}$ ), (RMS), (HYBRID), (EABS) and (MPSD) error function values. Therefore, while Langmuir and Dubinin-Radushkevich isotherm models are the most suitable isotherm models in terms of correlation coefficients, it is clear that the Temkin isotherm model is compared in terms of error functions.

Table 2

A few error function values of the isotherm models best suited to the experimental equilibrium data in the adsorption of AR35 dye on MBT.

\begin{tabular}{|lllllll|}
\hline Isotherm Model & APE $(\%)$ & $\mathbf{X}^{2}$ & Hybrid & MPSD & EABS & RMS \\
\hline Linear-Langmuir & 0.187 & 10.143 & 44.100 & 0.972 & 217.528 & 0.933 \\
\hline Freundlich & 0.054 & 0.843 & 3.667 & 0.280 & 62.730 & 0.269 \\
\hline Tempkin & 0.000 & 0.000 & 0.000 & 0.002 & 0.498 & 0.002 \\
\hline Dubinin-Radushkevich & 95.930 & 3820,34 & 104.272 & 140.299 & 2531.33 & 134.570 \\
\hline
\end{tabular}

\subsection{Adsorption Kinetic studies}

For the kinetic models of the adsorption of AR35 dye on MBT, pseudo-first-order (PFO) equation, pseudosecond-order (PSO) equation, Elovich equation, Intraparticle diffusion and Film diffusion equations were applied (El Nemr et al. 2010). The correlation coefficients $\left(R^{2}\right)$ of the kinetic models given in Tables 3-4 take a value between zero ( 0 ) and one (1), and the model's acceptance as a suitable model is directly related to the closeness of the $R^{2}$ value to one (1). As seen in Fig. 14a, rate constant, $k_{1}$ and equilibrium adsorption capacity $\left(q_{e}\right)$ is calculated from the linear graph of $l g\left(q_{e}-q_{t}\right)$ values against time $(t)$.

The significant deviation of the calculated $q_{e}$ values from the experimental values is related to the low $R^{2}$ values. Therefore, considering the values in Table 3, it means that the pseudo-first-order (PFO) kinetic equation is not very suitable for the adsorption of AR35 dye on MBT adsorbent. Table 3 shows that there is no regular increase or decrease in $R^{2}$ correlation coefficient values with the increase of MBT adsorbent concentration from 0.5 to $2.5 \mathrm{~g} \cdot \mathrm{L}^{-1}$.

The adsorption of AR35 dye on the MBT adsorbent was also analyzed using the pseudo-second-order (PSO) kinetic equation. As shown in Fig. 14b, it is possible to calculate the pseudo-second-order kinetic constant, $k_{2}\left(\mathrm{~g} \mathrm{mg}^{-1} \mathrm{~min}^{-1}\right)$ and the amount of AR35 dye adsorbed at equilibrium $\left(q_{e}\right)$ by plotting $t / q_{e}$ 
versus $t$. The PSO kinetic plot of MBT adsorbent for adsorption of AR35 dye is shown in Fig. 14b. In addition, the kinetic constant $\left(k_{2}\right)$ values, the experimentally and theoretically estimated $q_{e}$ values and the corresponding correlation coefficient $\left(R^{2}\right)$ values of the PSO equation are given in Table 3 . When Table 3 is examined, it is seen that the pseudo-second-order model is the model with $R^{2}$ values closest to 1 . Therefore, the most suitable kinetic model is the pseudo-second-order model. Thus, the $q_{e}$ values calculated using the PSO model plot and the experimental $q_{e}$ values exactly overlap for all initial AR35 dye concentrations studied.

Another kinetic model analyzed in the adsorption of AR35 dye on MBT adsorbent is the Elovich model, and Fig. 14c shows the correlation curve between $q_{t}$ and $\ln (t)$. The intersection point and slope of Fig. 14c were applied to the calculation of Elovich constants $a$ and $\beta$, respectively, and the obtained values are given in Table 4. When the $R^{2}$ values are compared, it can be said that the $R^{2}$ values of the Elovich model are higher than the PFO kinetic model values and lower than the PSO kinetic model values (Tables $3 \& 4$ ). According to the results from Tables $2 \& 3$, it is clear that chemical adsorption can determine the adsorption rate of AR35 dye on MBT adsorbent in some cases.

The intraparticle diffusion model is used to explain the transfer of solute in solid-liquid adsorption. The intraparticle diffusion model identifies and explains all the steps involved in the sorption process. In an adsorption process, the adsorbate is transferred onto the adsorbent in three successive steps: (i) The first step is concerned with the movement of ions or molecules transported from the solution through the liquid film to the adsorbent surface. (ii) The second step is that the ions or molecules attached to the adsorbent surface are then diffused into the adsorbent. (iii) The last step is the chemical reaction step that takes place in the active groups of the adsorbent. Each of these three steps takes place at a different rate, and the slowest step is also the step that determines the adsorption rate.

According to the theory put forward by Weber and Morris (1963), if the lines drawn in the graph of $q_{t}$ and root time $(t)$ in Fig. 14d pass through the origin, it is suggested that the adsorption is controlled by the intraparticle diffusion step. On the other hand, in the case where the drawn lines do not pass through the origin (where the $C$ value is large), it is assumed that the rate of the adsorption process is determined by film diffusion. The Webber-Morris adsorption line of the adsorption of AR35 dye on MBT adsorbent at different adsorbent doses and different initial AR35 dye concentrations is shown in Fig. $14 \mathrm{~d}$. The $K_{\text {dif }}$ and $C$ values shown in Table 4 were calculated from the slope and intercept point of the plot of $q t$ versus $t^{0.5}$, respectively. The straight lines of all adsorbent concentrations in Fig. 14d do not pass through the origin due to their high $C$ intersection. The reason for this situation can be shown that the rate of adsorption of AR35 dye on MBT adsorbent increases gradually over time, and as a result, this rate is controlled by film diffusion (Fig. 14e). The decrease in the pore volume and surface area of the MBT adsorbent during the adsorption process is the reason for this situation. 
Table 3

Pseudo-first-order kinetic model and pseudo-second-order kinetic model results of adsorption of AR35 dye (Initial concentration $\left.100-400 \mathrm{mg} \mathrm{L}^{-1}\right)$ by MBT adsorbent doses $\left(0.5-2.5 \mathrm{~g} \mathrm{~L}^{-1}\right)$, Temperature $\left(25 \pm 2^{\circ} \mathrm{C}\right)$.

\begin{tabular}{|c|c|c|c|c|c|c|c|c|}
\hline \multicolumn{3}{|c|}{ Parameter } & \multicolumn{3}{|c|}{ Pseudo-first-order } & \multicolumn{3}{|c|}{ Pseudo-second-order } \\
\hline $\begin{array}{l}\text { MBT } \\
(\mathbf{g} \\
\left.\mathrm{L}^{-1}\right)\end{array}$ & $\begin{array}{l}\text { AR35 dye (mg } \\
\left.L^{-1}\right)\end{array}$ & $\begin{array}{l}\mathrm{q}_{\mathrm{e}} \\
\text { (exp.) }\end{array}$ & $\begin{array}{l}\mathrm{q}_{\mathrm{e}} \\
\text { (calc.) }\end{array}$ & $\begin{array}{l}\mathrm{k}_{1} \times \\
10^{3}\end{array}$ & $\mathrm{R}^{2}$ & $\begin{array}{l}\mathrm{q}_{\mathrm{e}} \\
\text { (calc.) }\end{array}$ & $\begin{array}{l}k_{2} \times \\
10^{3}\end{array}$ & $\mathrm{R}^{2}$ \\
\hline \multirow[t]{5}{*}{0.5} & 100 & 195.3 & 73.8 & 40.99 & 0.836 & 196.1 & 1.91 & 1.000 \\
\hline & 150 & 294.0 & 369.15 & 43.76 & 0.735 & 303.0 & 0.34 & 0.996 \\
\hline & 200 & 390.2 & 747.48 & 43.76 & 0.638 & 416.7 & 0.14 & 0.986 \\
\hline & 300 & 428.7 & 466.44 & 25.56 & 0.807 & 476.2 & 0.08 & 0.948 \\
\hline & 400 & 465.7 & 2205.97 & 55.27 & 0.580 & 588.2 & 0.03 & 0.965 \\
\hline \multirow[t]{5}{*}{1.0} & 100 & 98.2 & 10.75 & 14.51 & 0.913 & 99.0 & 4.81 & 1.000 \\
\hline & 150 & 147.7 & 44.19 & 37.77 & 0.710 & 149.3 & 3.25 & 1.000 \\
\hline & 200 & 196.8 & 80.15 & 26.02 & 0.976 & 204.1 & 0.71 & 1.000 \\
\hline & 300 & 295.7 & 350.51 & 47.90 & 0.809 & 312.5 & 0.39 & 0.999 \\
\hline & 400 & 375.8 & 771.01 & 44.68 & 0.630 & 400.0 & 0.15 & 0.990 \\
\hline \multirow[t]{5}{*}{1.5} & 100 & 65.6 & 5.13 & 13.59 & 0.815 & 65.8 & 9.35 & 1.000 \\
\hline & 150 & 98.8 & 32.18 & 38.69 & 0.840 & 100.0 & 4.05 & 1.000 \\
\hline & 200 & 131.6 & 113.01 & 48.13 & 0.823 & 135.1 & 1.33 & 0.999 \\
\hline & 300 & 197.4 & 104.11 & 25.33 & 0.994 & 204.1 & 0.54 & 0.999 \\
\hline & 400 & 261.9 & 472.28 & 45.14 & 0.628 & 277.8 & 0.25 & 0.991 \\
\hline \multirow[t]{5}{*}{2.0} & 100 & 49.3 & 1.94 & 8.98 & 0.582 & 49.3 & 22.40 & 1.000 \\
\hline & 150 & 74.0 & 20.30 & 37.77 & 0.870 & 74.6 & 6.05 & 1.000 \\
\hline & 200 & 98.4 & 36.14 & 23.72 & 0.935 & 102.0 & 1.41 & 1.000 \\
\hline & 300 & 148.2 & 59.98 & 25.10 & 0.973 & 153.8 & 0.93 & 0.999 \\
\hline & 400 & 197.2 & 377.83 & 50.21 & 0.640 & 208.3 & 0.40 & 0.993 \\
\hline \multirow[t]{3}{*}{2.5} & 100 & 39.5 & 3.80 & 39.61 & 0.660 & 39.5 & 41.56 & 1.000 \\
\hline & 150 & 59.5 & 5.92 & 39.84 & 0.786 & 59.5 & 26.88 & 1.000 \\
\hline & 200 & 78.0 & 52.06 & 19.81 & 0.962 & 82.6 & 0.72 & 0.986 \\
\hline
\end{tabular}




\begin{tabular}{|cccccccc|}
\hline Parameter & \multicolumn{3}{c}{ Pseudo-first-order } & \multicolumn{3}{c|}{ Pseudo-second-order } \\
\hline 300 & 119.0 & 20.71 & 22.57 & 0.853 & 120.5 & 2.49 & 0.999 \\
\hline 400 & 158.6 & 79.84 & 29.25 & 0.918 & 169.5 & 0.56 & 0.993 \\
\hline
\end{tabular}


Table 4

Elovich, intraparticle diffusion and film diffusion models results of adsorption of AR35 dye (Initial concentration $\left.100-400 \mathrm{mg} \mathrm{L}^{-1}\right)$ by MBT adsorbent doses $\left(0.5-2.5 \mathrm{~g} \mathrm{~L}^{-1}\right)$, Temperature $\left(25 \pm 2^{\circ} \mathrm{C}\right)$.

\begin{tabular}{|c|c|c|c|c|c|c|c|c|c|}
\hline \multicolumn{2}{|c|}{ Parameter } & \multicolumn{3}{|c|}{ Elovich } & \multicolumn{3}{|c|}{ Intraparticle diffusion } & \multicolumn{2}{|c|}{ Film diffusion } \\
\hline $\begin{array}{l}\text { MBT } \\
\left(g \cdot L^{-1}\right)\end{array}$ & $\begin{array}{l}\text { AR35 dye } \\
\left(\mathrm{mg} \mathrm{L}^{-1}\right)\end{array}$ & $\beta$ & $a$ & $\mathrm{R}^{2}$ & $\mathrm{~K}_{\mathrm{dif}}$ & C & $\mathrm{R}^{2}$ & $\mathrm{~K}_{\mathrm{FD}}$ & $\mathrm{R}^{2}$ \\
\hline \multirow[t]{5}{*}{0.5} & 100 & 0.09 & 1601242 & 0.963 & 3.28 & 157.08 & 0.864 & -0.041 & 0.836 \\
\hline & 150 & 0.03 & 1051.23 & 0.934 & 10.57 & 162.57 & 0.965 & -0.044 & 0.735 \\
\hline & 200 & 0.02 & 337.43 & 0.891 & 17.44 & 161.02 & 0.978 & -0.044 & 0.638 \\
\hline & 300 & 0.02 & 170.92 & 0.725 & 22.20 & 126.45 & 0.906 & -0.016 & 0.929 \\
\hline & 400 & 0.01 & 33.59 & 0.973 & 34.50 & 27.60 & 0.943 & -0.055 & 0.581 \\
\hline \multirow[t]{5}{*}{1.0} & 100 & 0.26 & $3.3 \times 10^{9}$ & 0.926 & 1.14 & 84.05 & 0.892 & -0.016 & 0.902 \\
\hline & 150 & 0.14 & $2.7 \times 10^{7}$ & 0.967 & 2.02 & 123.71 & 0.824 & -0.038 & 0.710 \\
\hline & 200 & 0.04 & 293.53 & 0.967 & 7.44 & 111.03 & 0.822 & -0.028 & 0.978 \\
\hline & 300 & 0.03 & 1081.75 & 0.975 & 10.35 & 172.10 & 0.945 & -0.048 & 0.809 \\
\hline & 400 & 0.02 & 250.06 & 0.934 & 17.34 & 151.13 & 0.989 & -0.045 & 0.630 \\
\hline \multirow[t]{5}{*}{1.5} & 100 & 0.57 & $1.2 \times 10^{14}$ & 0.957 & 0.54 & 58.83 & 0.952 & -0.019 & 0.993 \\
\hline & 150 & 0.18 & $1.5 \times 10^{6}$ & 0.963 & 1.58 & 80.39 & 0.848 & -0.039 & 0.840 \\
\hline & 200 & 0.07 & 1132.61 & 0.974 & 4.01 & 85.17 & 0.879 & -0.048 & 0.823 \\
\hline & 300 & 0.04 & 323.29 & 0.981 & 7.69 & 104.87 & 0.937 & -0.025 & 0.992 \\
\hline & 400 & 0.03 & 628.78 & 0.872 & 10.23 & 126.92 & 0.980 & -0.045 & 0.628 \\
\hline \multirow[t]{5}{*}{2.0} & 100 & 1.36 & $5.2 \times 10^{26}$ & 0.990 & 0.23 & 46.41 & 0.956 & -0.015 & 0.985 \\
\hline & 150 & 0.20 & 116116.5 & 0.946 & 1.31 & 59.22 & 0.757 & -0.038 & 0.870 \\
\hline & 200 & 0.07 & 146.76 & 0.967 & 3.72 & 55.52 & 0.822 & -0.028 & 0.978 \\
\hline & 300 & 0.06 & 1189.04 & 0.990 & 4.66 & 92.36 & 0.940 & -0.028 & 0.984 \\
\hline & 400 & 0.04 & 463.83 & 0.865 & 7.62 & 100.61 & 0.943 & -0.050 & 0.640 \\
\hline \multirow[t]{3}{*}{2.5} & 100 & 2.72 & $8.9 \times 10^{43}$ & 0.964 & 0.11 & 38.07 & 0.947 & -0.040 & 0.600 \\
\hline & 150 & 0.96 & $4.6 \times 10^{22}$ & 0.904 & 0.28 & 56.28 & 0.728 & -0.040 & 0.786 \\
\hline & 200 & 0.10 & 67.48 & 0.891 & 3.48 & 32.20 & 0.978 & -0.005 & 0.965 \\
\hline
\end{tabular}




\begin{tabular}{|rllllllll|}
\hline \multicolumn{2}{|l}{ Parameter } & \multicolumn{2}{l}{ Elovich } & \multicolumn{3}{l}{ Intraparticle diffusion } & \multicolumn{2}{c|}{ Film diffusion } \\
\hline 300 & 0.20 & $3.3 \times 10^{8}$ & 0.782 & 1.67 & 98.39 & 0.898 & -0.007 & 0.956 \\
\hline 400 & 0.05 & 322.99 & 0.810 & 6.21 & 84.50 & 0.859 & -0.012 & 0.960 \\
\hline
\end{tabular}

In the literature review summarized in Table 5, since there is no study on the removal of Acid Red 35 dye the effectiveness of the removal of azo dyes using different adsorbents was compared with the MBT adsorbent and showed that MBT adsorbent was effective in removing AR35 dye. 
Table 5

Comparison of the maximum adsorption capacities of azo dyes of different adsorbents

\begin{tabular}{|c|c|c|c|c|}
\hline Adsorbent name & Azo dye & $\begin{array}{l}\text { Maximum } \\
\text { capacity } \\
\left(\mathrm{mg} \cdot \mathrm{g}^{-1}\right)\end{array}$ & $\begin{array}{l}\text { Maximum } \\
\text { Removal } \\
(\%)\end{array}$ & Ref. \\
\hline $\begin{array}{l}\text { Ethylenediamine-Modified } \\
\text { Peanut Husk }\end{array}$ & $\begin{array}{l}\text { Sunset } \\
\text { Yellow }\end{array}$ & 117.7 & - & (Song et al. 2015) \\
\hline \multirow[t]{2}{*}{ Mandarin Shells } & $\begin{array}{l}\text { Basic Blue } \\
9\end{array}$ & 294.0 & - & (Koyuncu et al. 2018) \\
\hline & $\begin{array}{l}\text { Acid Yellow } \\
36\end{array}$ & 417.0 & - & (Koyuncu et al. 2018) \\
\hline \multirow[t]{2}{*}{ Macore Fruit Shells } & $\begin{array}{l}\text { Methyl } \\
\text { Orange }\end{array}$ & 3.42 & 82.73 & (Aboua et al. 2015) \\
\hline & $\begin{array}{l}\text { Methylene } \\
\text { Blue }\end{array}$ & 10.61 & 91.31 & (Aboua et al. 2015) \\
\hline Orange Peel Carbon & $\begin{array}{l}\text { Direct } \\
\text { Yellow } 12\end{array}$ & 75.76 & 98.10 & (Aboua et al. 2015) \\
\hline \multirow[t]{5}{*}{ Sludge-Rice Husk Biochar } & Direct Red & 59.77 & - & (Chen et al. 2019) \\
\hline & \multirow{3}{*}{$\begin{array}{l}\text { Acid Orange } \\
\text { II } \\
\text { React Blue } \\
19\end{array}$} & 42.12 & - & (Chen et al. 2019) \\
\hline & & 38.46 & - & (Chen et al. 2019) \\
\hline & & 22.59 & - & (Chen et al. 2019) \\
\hline & $\begin{array}{l}\text { Methylene } \\
\text { Blue }\end{array}$ & & & \\
\hline $\begin{array}{l}\text { Biochar from gasification of } \\
\text { Wood Wastes }\end{array}$ & $\begin{array}{l}\text { Indosol } \\
\text { Black } \\
\text { NF1200 }\end{array}$ & 185.0 & 99.00 & (Kelm et al. 2019) \\
\hline \multirow[t]{2}{*}{ Mandarin Nanoporous Carbon } & $\begin{array}{l}\text { Methylene } \\
\text { Blue }\end{array}$ & 313.0 & - & (Koyuncu et al. 2020) \\
\hline & $\begin{array}{l}\text { Metanil } \\
\text { Yellow }\end{array}$ & 455.00 & - & (Koyuncu et al. 2020) \\
\hline \multirow[t]{2}{*}{ Mandarin Peel Biochar } & $\begin{array}{l}\text { Methyl } \\
\text { Orange }\end{array}$ & 16.27 & 99.00 & (Park et al. 2021) \\
\hline & Fast Green & 12.44 & 99.00 & (Park et al. 2021) \\
\hline \multirow[t]{2}{*}{ Carbonized Mandarin Peel } & $\begin{array}{l}\text { Methylene } \\
\text { Blue }\end{array}$ & 196.08 & 99.77 & \multirow{2}{*}{$\begin{array}{l}\text { (Unugul and Nigiz 2020) } \\
\text { (Unugul and Nigiz 2020) }\end{array}$} \\
\hline & $\begin{array}{l}\text { Methyl } \\
\text { Orange }\end{array}$ & - & 79.87 & \\
\hline
\end{tabular}




\begin{tabular}{|lllll|}
\hline Adsorbent name & Azo dye & $\begin{array}{l}\text { Maximum } \\
\text { capacity } \\
\left(\mathrm{mg}^{-1}\right)\end{array}$ & $\begin{array}{l}\text { Maximum } \\
\text { Removal } \\
(\%)\end{array}$ & Ref. \\
\hline $\begin{array}{l}\text { N-doped Biochars derived } \\
\text { from Phragmites Australis }\end{array}$ & Acid Red 18 & 134.17 & - & (Wang et al. 2018) \\
\hline MBT & Acid Red 35 & $\mathbf{4 7 6 . 1 9}$ & $\mathbf{9 9 . 0 0}$ & This work \\
\hline
\end{tabular}

\subsection{Regeneration of biochars}

Desorption experiments of AR35 dye from the loaded MBT were performed using $0.1 \mathrm{M} \mathrm{NaOH}$ followed by $0.1 \mathrm{~N} \mathrm{HCl}$ as eluted mediums to investigate the economic feasibility and reusability of MBT as an adsorbent. In this condition. the desorption \% decreased with rising regeneration cycles Fig. 15 . The regenerated MBT was applied in six consecutive cycles of adsorption/desorption. The adsorption amount presented was consistent through the cycles and experienced the adsorption capacity decreased by $12.7 \%$ after six generations. which suggests it may be used as a sustainable AR35 dye removal (Fig. 15).

\section{Conclusion}

In this study, it has been shown that mandarin peels, which are agricultural waste, can be used in the production of cheap and effective adsorbent material. MBT, which is prepared to be used in the removal of AR35 dye, an azo dye, was prepared by first treating dry mandarin peels with $50 \% \mathrm{H}_{2} \mathrm{SO}_{4}$ at boiling point, then oxidizing with ozone in water, and finally amination with Triethylenetetramine (TETA). The adsorption of AR35 dye was found to be dependent on adsorbent dose, initial concentration, contact time between the adsorbent and adsorbate and the $\mathrm{pH}$. It was determined that the optimum $\mathrm{pH}$ value of adsorption of AR35 dye by MBT adsorbent was 1.5. It was observed that the maximum removal of the AR35 dye and the minimum adsorption amount $\left(q_{e}\right)$ in the equilibrium were observed when the $2.5 \mathrm{~g} \mathrm{~L}^{-1}$ concentration of MBT adsorbent dose was used. In the removal of AR35 dye, the Dubinin-Radushkevich model is a better sorption process than other models. The maximum adsorption capacity calculated by using the Langmuir isotherm is $476.19 \mathrm{mg} \mathrm{g}^{-1}$. Considering the adsorption energy values obtained from Dubinin-Radushkevich isotherm models, it was determined that chemical adsorption may take place. As a result of this study, it is possible to use MBT as a cheap and effective potential adsorbent for the removal of AR35 dye from wastewater.

\section{Declarations}

\section{Funding}

This work was partially funded by the Science and Technology Development Fund (STDF) of Egypt (Projects Nos. CB-4874 and CB-22816).

\section{Data availability}


Data sharing does not apply to this article.

\section{Declarations}

Consent to participate Not applicable.

\section{Conflict of interest}

The authors declare no competing interests.

Informed Consent Statement: Not applicable.

\section{Author's contribution}

Eng. M.A. El-Nemr prepared the Biochar materials and provide biochar characterization, T.M. Eldeeb conducted the experimental of the removal work, calculation and theoritical models. Dr. M.A. Hassaan shared in experimental work, biochar characterization and supervise the experimental work. Dr. S. Ragab supervised the experimental work. Dr. M. Yılmaz conducted the theoritical modeling and calculation as well as wrote the original manuscript. Prof. A. El Nemr supervised the experimental work, completed the manuscript and provided financial support for the experiment work.

\section{References}

1. Abdelhafez AA, Li J (2016) Removal of $\mathrm{Pb}$ (II) from aqueous solution by using biochars derived from sugar cane bagasse and orange peel. J Taiwan Inst Chem Eng 61:367-375. https://doi.org/10.1016/j.jtice.2016.01.005

2. Abdelwahab O, El Sikaily A, Khaled A, El Nemr A (2007) Mass transfer processes of Chromium (VI) adsorption onto Guava seeds. Chem Ecol 23(1):73-85. https://doi.org/10.1080/02757540601083922

3. Aboua KN, Yobouet YA, YAO KB, Gone DL, Trokourey A (2015) Investigation of dye adsorption onto activated carbon from the shells of Macore fruit. J Environ Manage 156:10-14. https://doi.org/10.1016/j.jenvman.2015.03.006

4. Ahmad M, Rajapaksha AU, Lim JE, Zhang M, Bolan N, Mohan D, Vithanage M, Lee SS, Ok YS (2014) Biochar as a sorbent for contaminant management in soil and water: a review. Chemosphere 99:1933. https://doi.org/10.1016/j.chemosphere.2013.10.071

5. Anastopoulos I, Kyzas GZ (2014) Agricultural peels for dye adsorption: A review of recent literature. J Mol Liq 200:381-389. https://doi.org/10.1016/j.molliq.2014.11.006

6. Asiri HFM, Idris AM, Said TO, Sahlabji T, Alghamdi MM, El-Zahhar AA, El Nemr A (2020) Monitoring and health risk assessment of some pesticides and organic pollutants in fruit and vegetables consumed in Asir Region, Saudi Arabia. Fresenius Environ Bull 29(1):615-625

7. Azza Khaled AEN, El-Sikaily A, Abdelwahab O (2009) Treatment of artificial textile dye effluent containing Direct Yellow 12 by orange peel carbon. Desalination 238:210-232. 
https://doi.org/10.1016/j.desal.2008.02.014

8. Baquero M, Giraldo L, Moreno JC, Suarez-Garcı F, Martinez-Alonso A, Tascon JMD (2003) Activated carbons by pyrolysis of coffee bean husks in presence of phosphoric acid. J Anal Appl Pyrol 70(2):779-784. https://doi.org/10.1016/S0165-2370(02)00180-8

9. Barrett EP, Joyner LG, Halenda PP (1951) The Determination of Pore Volume and Area Distributions in Porous Substances. I. Computations from Nitrogen Isotherms. J Amer Chem Soc 73(1):373-380

10. Bilal M, Shah JA, Ashfaq T, Gardazi SMH, Tahir AA, Pervez A, Haroon H, Mahmood Q (2013) Waste biomass adsorbents for copper removal from industrial wastewater-a review. J Hazard Mater 263:322-333. https://doi.org/10.1016/j.jhazmat.2013.07.071

11. Boluda-Aguilar M, Garcia-Vidal L, Gonzalez-Castaneda FDP, Lopez-Gomez A (2010) Mandarin peel wastes pretreatment with steam explosion for bioethanol production. Bioresour Technol 101(10):3506-3513. https://doi.org/10.1016/j.biortech.2009.12.063

12. Chang J, Ma Q, Ma J, Ma H (2016) Synthesis of $\mathrm{Fe}_{3} \mathrm{O}_{4}$ nanowire@ $\mathrm{CeO}_{2} / \mathrm{Ag}$ nanocomposites with enhanced photocatalytic activity under sunlight exposure. Ceram Int 42(10):11827-11837. https://doi.org/10.1016/j.ceramint.2016.04.104

13. Chang Z, Tian L, Wu M, Dong X, Peng J, Pan B (2018) Molecular markers of benzene polycarboxylic acids in describing biochar physiochemical properties and sorption characteristics. Environ Pollut 237:541-548. https://doi.org/10.1016/j.envpol.2018.02.071

14. Chao HP, Chang CC, Nieva A (2014) Biosorption of heavy metals on Citrus maxima peel, passion fruit shell, and sugarcane bagasse in a fixed-bed column. J Ind Eng Chem 20(5):3408-3414. https://doi.org/10.1016/j.jiec.2013.12.027

15. Chen S, Qin C, Wang T, Chen F, Li X, Hou H, Zhou M (2019) Study on the adsorption of dyestuffs with different properties by sludge-rice husk biochar: Adsorption capacity, isotherm, kinetic, thermodynamics and mechanism. J Mol Liq 285:62-74. https://doi.org/10.1016/j.molliq.2019.04.035

16. Chowdhury S, Chakraborty S, Saha P (2011) Biosorption of Basic Green 4 from aqueous solution by Ananas comosus (pineapple) leaf powder. Colloids Surf B Biointerfaces 84(2):520-527. https://doi.org/10.1016/j.colsurfb.2011.02.009

17. Cuerda-Correa EM, Dominguez-Vargas JR, Olivares-Marin FJ, de Heredia JB (2010) On the use of carbon blacks as potential low-cost adsorbents for the removal of non-steroidal anti-inflammatory drugs from river water. J Hazard Mater 177(1-3):1046-1053.

https://doi.org/10.1016/j.jhazmat.2010.01.026

18. Dawood S, Sen TK (2012) Removal of anionic dye Congo red from aqueous solution by raw pine and acid-treated pine cone powder as adsorbent: equilibrium, thermodynamic, kinetics, mechanism and process design. Water Res 46(6):1933-1946. https://doi.org/10.1016/j.watres.2012.01.009

19. Dhillon SS, Gill R, Gill SS, Singh M (2004) Studies on the utilization of citrus peel for pectinase production using fungus Aspergillus niger. Int J Environ Stud 61(2):199-210.

https://doi.org/10.1080/0020723032000143346 
20. El Nemr A (2005) Petroleum contamination in warm and cold marine environment. Nova Science Publishers, Inc., Hauppauge New York. [ISBN 1-59454-615-0] 150pp

21. El Nemr A (2011) Impact, Monitoring and Management of Environmental Pollution. Nova Science Publishers, Inc., Hauppauge New York. [ISBN-10: 1608764877, ISBN-13: 9781608764877]. 638 pages

22. El Nemr A (2012a) Textiles: Types, Uses and Production Methods. Nova Science Publishers, Inc. Hauppauge New York. Hard cover [ISBN: 978-1-62100-239-0], e-book [ISBN: 978-1-62100-284-0] 621 pages

23. El Nemr A (2012b) Environmental Pollution and its relation to Climate Change. Nova Science Publishers, Inc., Hauppauge New York. [ISBN-13: 978-1-61761-794-2] 694 pages

24. El Nemr A (2012c) Non-Conventional textile waste water treatment. Nova Science Publishers, Inc. Hauppauge New York. [Hard cover ISBN: 978-1-62100-079-2, e-book ISBN: 978-1-62100-228-4] 267 pages

25. El Nemr A (2016) Pollution Status, Environmental Protection, and Renewable Energy production in Marine Systems. Nova Science Publishers, Inc. Hauppauge New York. [Hard cover ISBN: 978-163484-047-7, e-Book. ISBN: 978-1-63484-282-2]

26. El Nemr A, Aboughaly RM, El Sikaily A, Ragab S, Masoud MS, Ramadan MS (2021a) Utilization of Citrus aurantium peels for sustainable production of high surface area type I microporous nano activated carbons. Biomass Convers Biorefinery. https://doi.org/10.1007/s13399-021-01457-2

27. El Nemr A, Aboughaly RM, El Sikaily A, Ragab S, Masoud MS, Ramadan MS (2021c) Utilization of sugarcane bagasse/ $\mathrm{ZnCl}_{2}$ for sustainable production of microporous nano activated carbons of type I for toxic $\mathrm{Cr}(\mathrm{VI})$ removal from aqueous environment. Biomass Convers Biorefinery. https://doi.org/10.1007/s13399-021-01445-6

28. El Nemr A, El Sikaily A, Khaled A, Said TO, Abd-Alla AMA (2004) Determination of hydrocarbons in mussels from the Egyptian Red Sea Coast. Environ Monit Assess 96(1-3):251-261. http://dx.doi.org/10.1023/B:EMAS.0000031731.88863.25

29. El Nemr A, El-Sadaawy MM (2016) Polychlorinated biphenyl and organochlorine pesticide residues in surface sediments from the Mediterranean Sea (Egypt). Int J Sedim Res 31:44-52.

https://doi.org/10.1016/j.ijsrc.2013.03.001

30. El Nemr A, El-Sadaawy MM, Khaled A, Draz SO (2013) Aliphatic and polycyclic aromatic hydrocarbons in the surface sediments of the Mediterranean: assessment and source recognition of petroleum hydrocarbons. Environ Monit Assess 185:4571-4589. http://dx.doi.org/10.1007/s10661012-2889-1

31. El Nemr A, El-Said GF, Khaled A (2016) Risk assessment of Organochlorines in molluscs from the Mediterranean and Red Sea coasts (Egypt). Water Environ Res 88(4):325-337. http://dx.doi.org/10.2175/106143016X14504669767977

32. El Nemr A, Hassaan MA, Madkour FF (2017) HPLC-MS/MS Mechanistic study of Direct Yellow 12 degradation using Ultraviolet assisted ozone process. J Water Environ Nanatechnol 3(1):1-11. https://doi.org/10.22090/jwent.2018.01.001 
33. El Nemr A, Hassaan MA, Madkour FF (2018) Advanced oxidation process (AOP) for detoxification of acid red 17 dye solution and degradation mechanism. Environ processes 5:95-113. https://doi.org/10.1007/s40710-018-0284-9

34. El Nemr A, Helmy ET, Arafa E, Eldafrawy S, Mousa M (2019) Photocatalytic and biological activities of undoped and doped $\mathrm{TiO}_{2}$ prepared by Green method for water treatment. J Environ Chem Eng 7(5):103385. https://doi.org/10.1016/j.jece.2019.103385

35. El Nemr A, Khaled AE-SA (2010) Modeling of adsorption isotherms of Methylene Blue onto rice husk activated carbon. Egypt J Aquat Res 36:403-425

36. El Nemr A, Shoaib AGM, El Sikaily A, Mohamed AE-DA, Hassan AF (2021b) Evaluation of cationic Methylene blue dye removal by high surface area mesoporous nano activated carbon derived from Ulva lactuca. Environ Processes 8(1):311-332. https://doi.org/10.1007/s40710-020-00487-8

37. El Qada EN, Allen SJ, Walker GM (2006) Adsorption of Methylene Blue onto activated carbon produced from steam activated bituminous coal: A study of equilibrium adsorption isotherm. Chem Eng J 124(1-3):103-110. https://doi.org/10.1016/j.cej.2006.08.015

38. Eldeeb TM, El Nemr A, Khedr MH, El-Dek SI (2021) Novel bio-nanocomposite for efficient copper removal. Egypt J Aquat Res 47(3):261-267. https://doi.org/10.1016/j.ejar.2021.07.002

39. El-Nemr MA, Abdelmonem NM, Ismail IMA, Ragab S, El Nemr A (2020b) The efficient removal of the hazardous Azo Dye Acid Orange 7 from water using modified biochar from Pea peels. Desalination Water Treat 203:327-355. https://doi.org/10.5004/dwt.2020.26190

40. El-Nemr MA, Abdelmonem NM, Ismail IMA, Ragab S, El Nemr A (2020c) Removal of Acid Yellow 11 Dye using novel modified biochar derived from Watermelon Peels. Desalin Water Treat 203:403-431. https://doi.org/10.5004/dwt.2020.26207

41. El-Nemr MA, Abdelmonem NM, Ismail IMA, Ragab S, El-Nemr A (2020) Removal of Acid Yellow 11 dye using a novel modified biochar derived from watermelon peels. Desalination Water Treat 203:403431. https://doi.org/10.5004/dwt.2020.26207

42. El-Nemr MA, Aigbe UO, Hassaan MA, Ukhurebor KE, Ragab S, Onyancha RB, Osibote OA, El Nemr A (2022a) The use of biochar- $\mathrm{NH}_{2}$ produced from watermelon peels as a natural adsorbent for the removal of $\mathrm{Cu}$ (II) ions from water. Biomass Convers Biorefinery. https://doi.org/10.1007/s13399-02202327-1

43. El-Nemr MA, Ismail IMA, Abdelmonem NM, El Nemr A, Ragab S (2021) Amination of biochar derived from Watermelon peel by Triethylenetetramine and ammonium hydroxide for toxic chromium removal enhancement. Chinese Journal of Chemical Engineering 36: 199-222. https://doi.org/S10049541(20)30464-X

44. El-Nemr MA, Ismail IMA, Abdelmonem NM, Ragab S, El Nemr A (2020a) Ozone and Ammonium Hydroxide Modification of Biochar Prepared from Pisum sativum Peels Improves the Adsorption of Copper (II) from an Aqueous Medium. Environ Processes 7:973-1007. https://doi.org/10.1007/s40710-020-00455-2 
45. El-Nemr MA, Yılmaz M, Ragab S, El Nemr A (2022b) Biochar-SO Prepared from Pea Peels by Dehydration with Sulfuric Acid Improves the Adsorption of $\mathrm{Cr}^{6+}$ from Water. Biomass Conversion and Biorefinery. In press 20, 01, 2022

46. FAO (2021) World Food and Agriculture - Statistical Yearbook 2021. Rome. https://doi.org/10.4060/cb4477en

47. Felix C, Yaroshchuk A, Pasupathi S, Pollet BG, Bondarenko MP, Kovalchuk VI, Zholkovskiy EK (2014) Electrophoresis and stability of nano-colloids: history, theory and experimental examples. Adv Colloid Interface Sci 211:77-92. https://doi.org/10.1016/j.cis.2014.06.005

48. Feng $Y$, Yang F, Wang $Y$, Ma Li, Wu Y, Kerr PG, Yang $L$ (2011) Basic dye adsorption onto an agro-based waste material-sesame hull (Sesamum indicum L.). Bioresour Technol 102(22):10280-10285. https://doi.org/10.1016/j.biortech.2011.08.090

49. Foo KY, Hameed BH (2012) Coconut husk derived activated carbon via microwave induced activation: Effects of activation agents, preparation parameters and adsorption performance. Chem Eng J 184:57-65. https://doi.org/10.1016/j.cej.2011.12.084

50. Fu J, Chen Z, Wang M, Liu S, Zhang J, Zhang J, Han R, Xu Q (2015) Adsorption of methylene blue by a high-efficiency adsorbent (polydopamine microspheres): Kinetics, isotherm, thermodynamics and mechanism analysis. Chem Eng J 259:53-61. https://doi.org/10.1016/j.cej.2014.07.101

51. Gregg SJ, Sing KSW (1982) Adsorption Surface Area and Porosity, 2nd edn. Academic Press INC., London

52. Gupta N, Kushwaha AK, Chattopadhyaya MC (2016) Application of potato (Solanum tuberosum) plant wastes for the removal of methylene blue and malachite green dye from aqueous solution. Arab J Chem 9:S707-S716. https://doi.org/10.1016/j.arabjc.2011.07.021

53. Gupta VK, Nayak A, Agarwal S (2015) Bioadsorbents for remediation of heavy metals: Current status and their future prospects. Environ Eng Res 20(1):1-18. https://doi.org/10.4491/eer.2015.018

54. Güzel F, Sayğılı H, Sayğılı GA, Koyuncu F, Yılmaz C (2017) Optimal oxidation with nitric acid of biochar derived from pyrolysis of weeds and its application in removal of hazardous dye methylene blue from aqueous solution. J Clean Prod 144:260-265.

https://doi.org/10.1016/j.jclepro.2017.01.029

55. Hassaan MA, El Nemr A (2020) Pesticides Pollution: Classifications, Human Health Impact, Extraction and Treatment Techniques. Egypt J Aquat Res 46(3):207-220. https://doi.org/10.1016/j.ejar.2020.08.007

56. Hassaan MA, El Nemr A, Elkatory MR, Ragab S, El-Nemr MA, Pantaleo A (2021) Synthesis, Characterization, and Synergistic Effects of Modified Biochar in Combination with a- $\mathrm{Fe}_{2} \mathrm{O}_{3} \mathrm{NPs}$ on Biogas Production from Red Algae Pterocladia capillacea. Sustainability 13(16):9275. https://doi.org/10.3390/su13169275

57. Hassaan MA, El Nemr A, Madkour FF (2017a) Testing the Advanced Oxidation Processes on the Degradation of Direct Blue 86 Dye in Wastewater. Egypt Jurnal Aquat Res 43:11-19. https://doi.org/10.1016/j.ejar.2016.09.006

Page 27/41 
58. Hassaan MA, El Nemr A, Madkour FF (2017b) Advanced Oxidation Processes of Mordant Violet 40 Dye in Freshwater and Seawater. Egypt $J$ Aquat Res 43:1-9. https://doi.org/10.1016/j.ejar.2016.09.004

59. Heibati B, Rodriquez-Couto S, Al-Ghouti MA, Asif M, Tyagi I, Agarwal S, Gupta VK (2015) Kinetics and thermodynamics of enhanced adsorption of the dye AR 18 using activated carbons prepared from walnut and poplar woods. J Mol Liq 208:99-105. https://doi.org/10.1016/j.molliq.2015.03.057

60. Helmy ET, El Nemr A, Gomaa E, El Dafrawy S, Mousa M (2021) Photocatalytic degradation of textile dyeing wastewater under visible light irradiation using green synthesized mesoporous non-metal doped $\mathrm{TiO}_{2}$. Bull Mater Sci 44:30. https://doi.org/10.1007/s12034.020-02322-0

61. Helmy ET, El Nemr A, Mousa M, Arafa E, Eldafrawy S (2018) Photocatalytic degradation of organic dyes pollutants in the industrial textile wastewater by using synthesized $\mathrm{TiO}_{2}, \mathrm{C}$-doped $\mathrm{TiO}_{2}, \mathrm{~S}$-doped $\mathrm{TiO}_{2}$ and $\mathrm{C}, \mathrm{S}$ co-doped $\mathrm{TiO}_{2}$ nanoparticles. J Water Environ Nanatechnol 3(2):116-127. https://dx.doi.org/10.22090/jwent.2018.02.003

62. Ignatowicz K (2009) Selection of sorbent for removing pesticides during water treatment. J Hazard Mater 169(1-3).

953-7

.. https://doi.org/10.1016/j.jhazmat.2009.04.061

63. Iqbal M (2016) Vicia faba bioassay for environmental toxicity monitoring: A review. Chemosphere 144:785-802

64. Islam MA, Benhouria A, Asif M, Hameed BH (2015) Methylene blue adsorption on factory-rejected tea activated carbon prepared by conjunction of hydrothermal carbonization and sodium hydroxide activation processes. J Taiwan Inst Chem Eng 52:57-64. https://doi.org/10.1016/j.jtice.2015.02.010

65. Jimenez-Cordero D, Heras F, Alonso-Morales N, Gilarranz MA, Rodriguez JJ (2015) Ozone as oxidation agent in cyclic activation of biochar. Fuel Processing Technology 139: 42-48. https://doi.org/10.1016/j.fuproc.2015.08.016

66. Karthikeyan S, Gupta VK, Boopathy R, Titus A, Sekaran G (2012) A new approach for the degradation of high concentration of aromatic amine by heterocatalytic Fenton oxidation: Kinetic and spectroscopic studies. J Mol Liq 173:153-163. https://doi.org/10.1016/j.molliq.2012.06.022

67. Kelm MAP, Junior MJdaS, Holanda SHdeB, CMBde A, Freitas FRBdeA, Santos EJ, Sobrinho DRD MAdeM (2019) Removal of azo dye from water via adsorption on biochar produced by the gasification of wood wastes. Environ Sci Pollut Res Int 26(28):28558-28573. https://doi.org/10.1007/s11356-018-3833-x

68. Kim I, Saif Ur Rehman M, Han J-I (2014) Fermentable sugar recovery and adsorption potential of enzymatically hydrolyzed rice straw. J Clean Prod 66:555-561

69. Kołodyńska D, Krukowska J, Thomas P (2017) Comparison of sorption and desorption studies of heavy metal ions from biochar and commercial active carbon. Chem Eng J 307:353-363

70. Koyuncu F, Güzel F (2020) Use of new nanoporous carbon produced from Mandarin (Citrus reticulata) industrial processing waste to remove anionic and cationic dyes. Sep Sci Technol 
56(6):1001-1013

71. Koyuncu F, Güzel F, Sayğılı H (2018) Role of optimization parameters in the production of nanoporous carbon from mandarin shells by microwave-assisted chemical activation and utilization as dye adsorbent. Adv Powder Technol 29(9):2108-2118. https://doi.org/10.1016/j.apt.2018.05.019

72. Kyzas GZ, Deliyanni EA, Matis KA (2016) Activated carbons produced by pyrolysis of waste potato peels: Cobalt ions removal by adsorption. Colloids Surf A 490:74-83

73. Liatsou I, Michail G, Demetriou M, Pashalidis I (2016) Uranium binding by biochar fibres derived from Luffa cylindrica after controlled surface oxidation. J Radioanal Nucl Chem 311(1):871-875. https://doi.org/10.1007/s10967-016-5063-3

74. Lin Q, Gao M, Chang J, Ma H (2016) Adsorption properties of crosslinking carboxymethyl cellulose grafting dimethyldiallylammonium chloride for cationic and anionic dyes. Carbohydr Polym 151:283-294. https://doi.org/10.1016/j.carbpol.2016.05.064

75. Lin Q, Wang K, Gao M, Bai Y, Chen L, Ma H (2017) Effectively removal of cationic and anionic dyes by $\mathrm{pH}$-sensitive amphoteric adsorbent derived from agricultural waste-wheat straw. J Taiwan Inst Chem Eng 76:65-72. https://doi.org/10.1016/j.jtice.2017.04.010

76. Liu WJ, Zeng FX, Jiang H, Zhang XS (2011) Preparation of high adsorption capacity bio-chars from waste biomass. Bioresour Technol 102(17):8247-8252. https://doi.org/10.1016/j.biortech.2011.06.014

77. Liu X, Zhang Y, Li Z, Feng R, Zhang Y (2014) Characterization of corncob-derived biochar and pyrolysis kinetics in comparison with corn stalk and sawdust. Bioresour Technol 170:76-82. https://doi.org/10.1016/j.biortech.2014.07.077

78. Ma Y, Liu WJ, Zhang N, Li YS, Jiang H, Sheng GP (2014) Polyethylenimine modified biochar adsorbent for hexavalent chromium removal from the aqueous solution. Bioresour Technol 169:403408. https://doi.org/10.1016/j.biortech.2014.07.014

79. Madhusudan P, Kumar MV, Ishigaki T, Toda K, Uematsu K, Sato M (2013) Hydrothermal synthesis of meso/macroporous $\mathrm{BiVO}_{4}$ hierarchical particles and their photocatalytic degradation properties under visible light irradiation. Environ Sci Pollut Res Int 20(9):6638-6645. https://doi.org/10.1007/s11356-013-1694-x

80. Mobasherpour I, Pazouki ESM (2012) Comparative of the removal of $\mathrm{Pb}^{2+}, \mathrm{Cd}^{2+}$ and $\mathrm{Ni}^{2+}$ by nano crystallite hydroxyapatite from aqueous solutions: Adsorption isotherm study. Arab J Chem 5:439446

81. Park H, Kim J, Lee YG, Chon K (2021) Enhanced Adsorptive Removal of Dyes Using Mandarin Peel Biochars via Chemical Activation with $\mathrm{NH}_{4} \mathrm{Cl}$ and $\mathrm{ZnCl}_{2}$. Water 13(11). https://doi.org/10.3390/w13111495

82. Ponnusami V, Gunasekar V, Srivastava SN (2009) Kinetics of methylene blue removal from aqueous solution using gulmohar (Delonix regia) plant leaf powder: multivariate regression analysis. J Hazard Mater 169(1-3):119-127 
83. Rafatullah M, Sulaiman O, Hashim R, Ahmad A (2010) Adsorption of methylene blue on low-cost adsorbents: a review. J Hazard Mater 177(1-3):70-80.

https://doi.org/10.1016/j.jhazmat.2009.12.047

84. Ragab S, El Sikaily A, El Nemr A (2016) Concentrations and Sources of Pesticides and PCBs in Surficial Sediments of the Red Sea Coast, Egypt. Egypt J Aquat Res 42:365-374

85. Rauf MA, Ashraf SS (2009) Radiation induced degradation of dyes--an overview. J Hazard Mater 166(1):6-16

86. Rouquerol F, Rouquerol J, Sing KSW (1999) Adsorption by Powders and Porous Solids. Academic Press INC., London

87. Sahlabji T, El-Nemr MA, El Nemr A, Ragab S, Alghamdi MM, El-Zahhar AA, Idris AM, Said TO (2021) High Surface Area Microporous Activated Carbon from Pisum sativum peels for Hexavalent Chromium Removal from Aquatic Environment. Toxin Reviews. In Press 22, 03, 2021. https://doi.org/10.1080/15569543.2021.1908361

88. Salama A, Shukry N, El-Sakhawy M (2015) Carboxymethyl cellulose-g-poly(2-(dimethylamino) ethyl methacrylate) hydrogel as adsorbent for dye removal. Int J Biol Macromol 73:72-75

89. Salarirad MM, Behnamfard A (2011) Modeling of equilibrium data for free cyanide adsorption onto activated carbon by linear and non-linear regression methods. 2011 International Conference on Environment and Industrial Innovation IPCBEE 12: 1-6

90. Saleh TA, Gupta VK (2012) Column with CNT/magnesium oxide composite for lead(II) removal from water. Environ Sci Pollut Res Int 19(4):1224-1228

91. Salem DMS, Khaled A, El Nemr A (2013) Assessment of pesticides and polychlorinated biphenyls (PCBs) in sediments of the Egyptian Mediterranean Coast. Egypt J Aquat Res 39(2):141-152. http://dx.doi.org/10.1016/j.ejar.2013.11.001

92. Salem DMSA, El Sikaily A, El Nemr A (2014) Organocholorines and their risk in marine shellfish collected from the Mediterranean coast, Egypt. Egypt J Aquat Res 40:93-101. http://dx.doi.org/10.1016/j.ejar.2014.03.004

93. Shakoor S, Nasar A (2017) Adsorptive treatment of hazardous methylene blue dye from artificially contaminated water using cucumis sativus peel waste as a low-cost adsorbent. Groundw Sustainable Dev 5:152-159

94. Shoaib AGM, El-Sikaily A, El Nemr A, Mohamed AE-DA, Hassan AF (2021a) Testing the carbonization condition for high surface area preparation of activated carbon followed Type IV from green alga Ulva lactuca. Biomass Conversion and Biorefinery. In press 11, 06, 2020. https://doi.org/10.1007/s13399-020-00823-w

95. Shoaib AGM, El-Sikaily A, El Nemr A, Mohamed AE-DA, Hassan AF (2021b) Preparation and characterization of highly surface area activated carbons followed Type IV from marine red alga (Pterocladia capillacea) by zinc chloride activation. Biomass Conversion and Biorefinery. In press 04, 05, 2020. https://doi.org/10.1007/s13399-020-00760-8 
96. Slaný M, Jankovic L, Madejová J (2019) Structural characterization of organo-montmorillonites prepared from a series of primary alkylamines salts: Mid-IR and near-IR study. Appl Clay Sci 176:1120

97. Song J, Zou W, Bian Y, Su F, Han R (2011) Adsorption characteristics of methylene blue by peanut husk in batch and column modes. Desalination 265(1-3):119-125. https://doi.org/10.1016/j.desal.2010.07.041

98. Song Y, Xu H, Ren J (2015) Adsorption study for removal of sunset yellow by ethylenediaminemodified peanut husk. Desalination Water Treat 57(37):17585-17592

99. Song Z, Lian F, Yu Z, Zhu L, Xing B, Qiu W (2014) Synthesis and characterization of a novel MnOxloaded biochar and its adsorption properties for $\mathrm{Cu}^{2+}$ in aqueous solution. Chem Eng J 242:36-42. https://doi.org/10.1016/j.cej.2013.12.061

100. Unugul T, Nigiz FU (2020) Preparation and Characterization an Active Carbon Adsorbent from Waste Mandarin Peel and Determination of Adsorption Behavior on Removal of Synthetic Dye Solutions. Water, Air, \& Soil Pollution231(11)

101. Unugul T, Nigiz FU (2020) Synthesis of acid treated carbonized mandarin peel for purification of copper. Water Pract Technol 15(2):460-471

102. Walter J, Weber JCM (1963) Kinetics of Adsorption on Carbon from Solution. J Sanit Eng Div 89:3160

103. Wang L, Yan W, He C, Wen H, Cai Z, Wang Z, Chen Z, Liu W (2018) Microwave-assisted preparation of nitrogen-doped biochars by ammonium acetate activation for adsorption of acid red 18. Appl Surf Sci 433:222-231. https://doi.org/10.1016/j.apsusc.2017.10.031

104. Wang Li, Wang Y, Ma F, Tankpa V, Bai S, Guo X, Wang X (2019) Mechanisms and reutilization of modified biochar used for removal of heavy metals from wastewater: A review. Sci Total Environ 668:1298-1309. https://doi.org/10.1016/j.scitotenv.2019.03.011

105. Yao Y, Gao B, Feng J, Zhang M, Chen H, Zhou Y, Creamer AE, Sun Y, Yang L (2014) Characterization and environmental applications of clay-biochar composites. Chem Eng J 242:136-143. https://doi.org/10.1016/j.cej.2013.12.062

106. Yavuz R, Akyildiz H, Karatepe N, Çetinkaya E (2010) Influence of preparation conditions on porous structures of olive stone activated by $\mathrm{H}_{3} \mathrm{PO}_{4}$. Fuel Processing Technology 91(1): 80-87. https://doi.org/10.1016/j.fuproc.2009.08.018

107. Yeboah ML, Li X, Zhou S (2020) Facile fabrication of biochar from palm kernel shell waste and its novel application to magnesium-based materials for hydrogen storage. Materials 13(3):625

108. Yıldırım GM, Bayrak B (2021) The synthesis of biochar-supported nano zero-valent iron composite and its adsorption performance in removal of malachite green. Biomass Convers Biorefinery 1-13. https://doi.org/10.1007/s13399-021-01501-1

109. Zhang H, Hay AG (2020) Magnetic biochar derived from biosolids via hydrothermal carbonization: Enzyme immobilization, immobilized-enzyme kinetics, environmental toxicity. J Hazard Mater $384: 121272$ 
110. Zhang W, Li H, Kan X, Dong L, Yan H, Jiang Z, Yang H, Li A, Cheng R (2012) Adsorption of anionic dyes from aqueous solutions using chemically modified straw. Bioresour Technol 117:40-47. https://doi.org/10.1016/j.biortech.2012.04.064

\section{Figures}

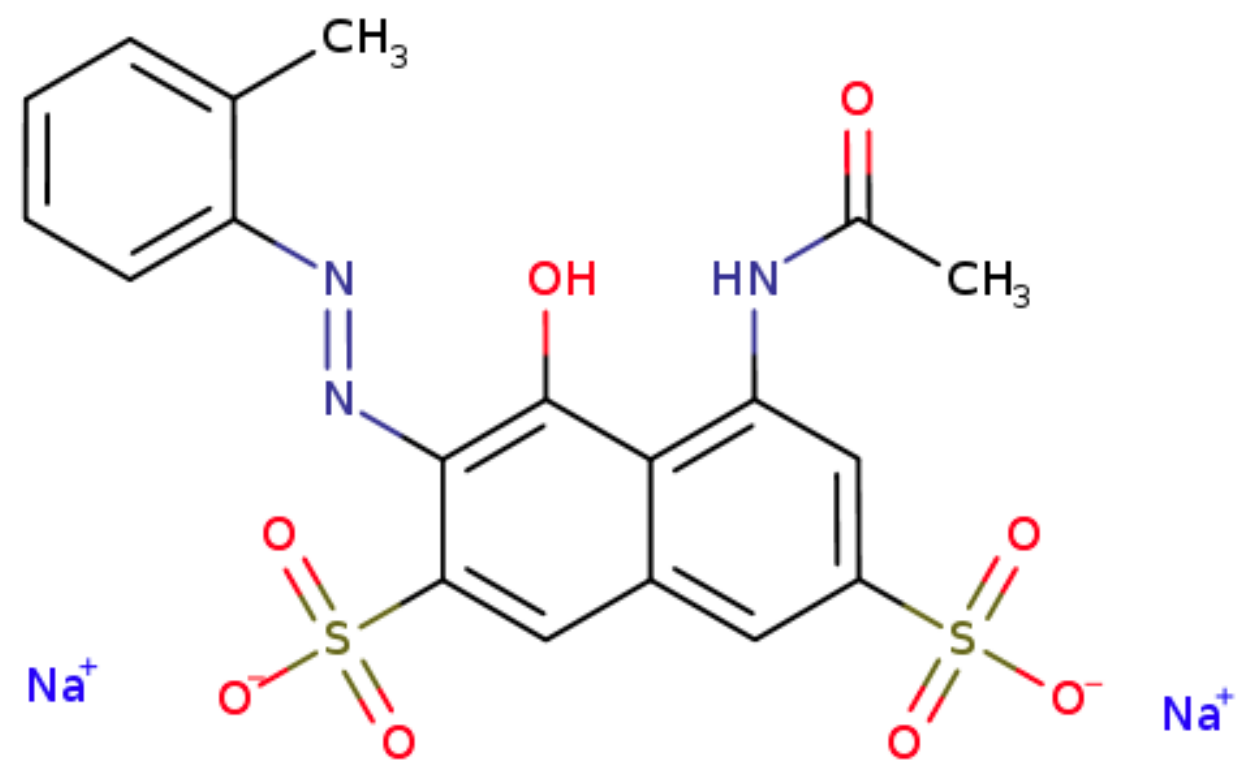

\section{Figure 1}

Chemical structure of AR35 dye (MF: $\mathrm{C}_{20} \mathrm{H}_{16} \mathrm{~N}_{4} \mathrm{O}_{9} \mathrm{~S}_{2} \mathrm{Na}_{2}$ ) (MW:566.47g/mol) (C.I.18055) (Other names: Amido Red 6B, Rose 6B, Acid Red 6B) (CAS number:4321-69-1) 


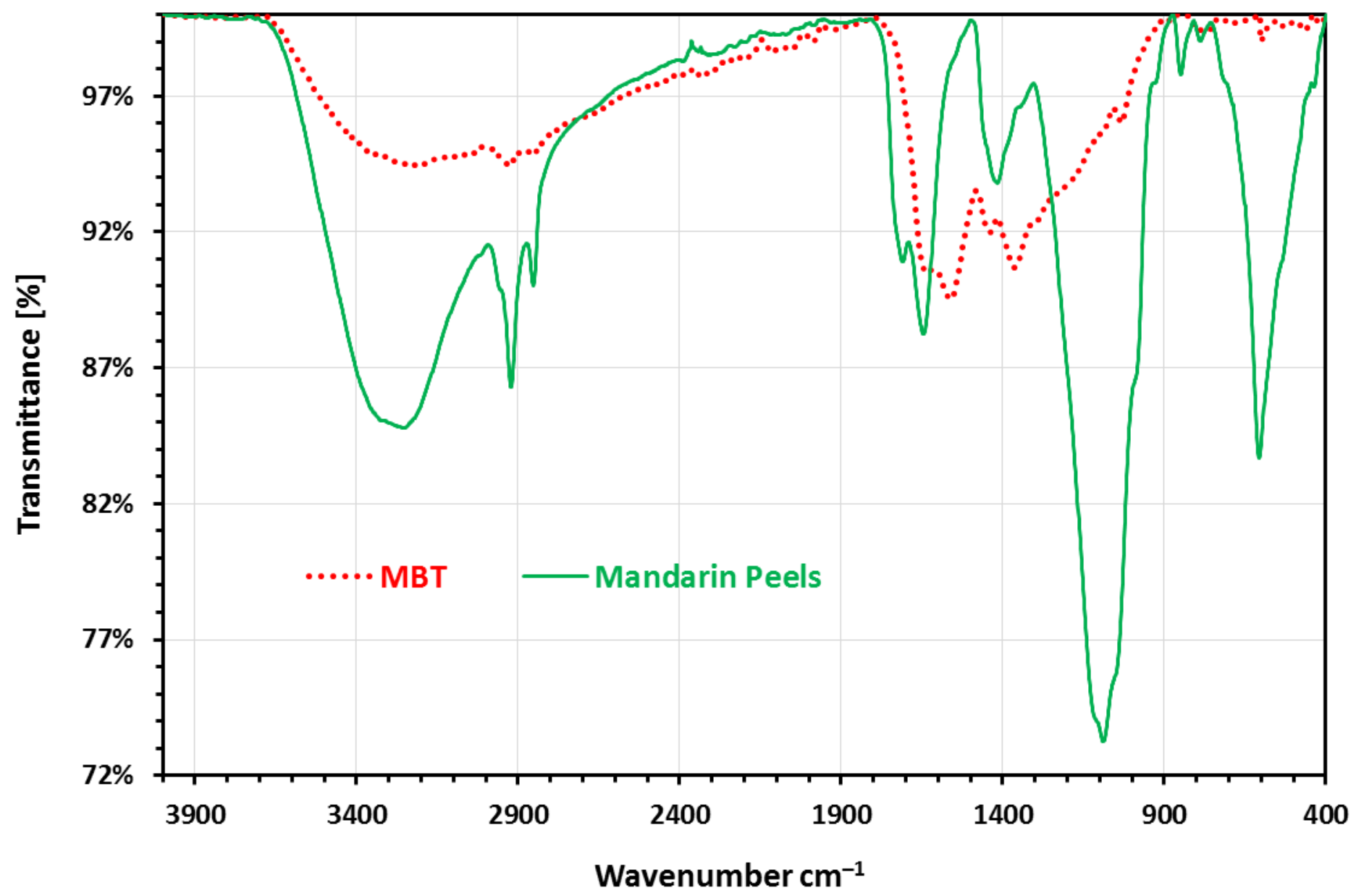

Figure 2

FTIR analysis of Mandarin peels and MBT adsorbent. 

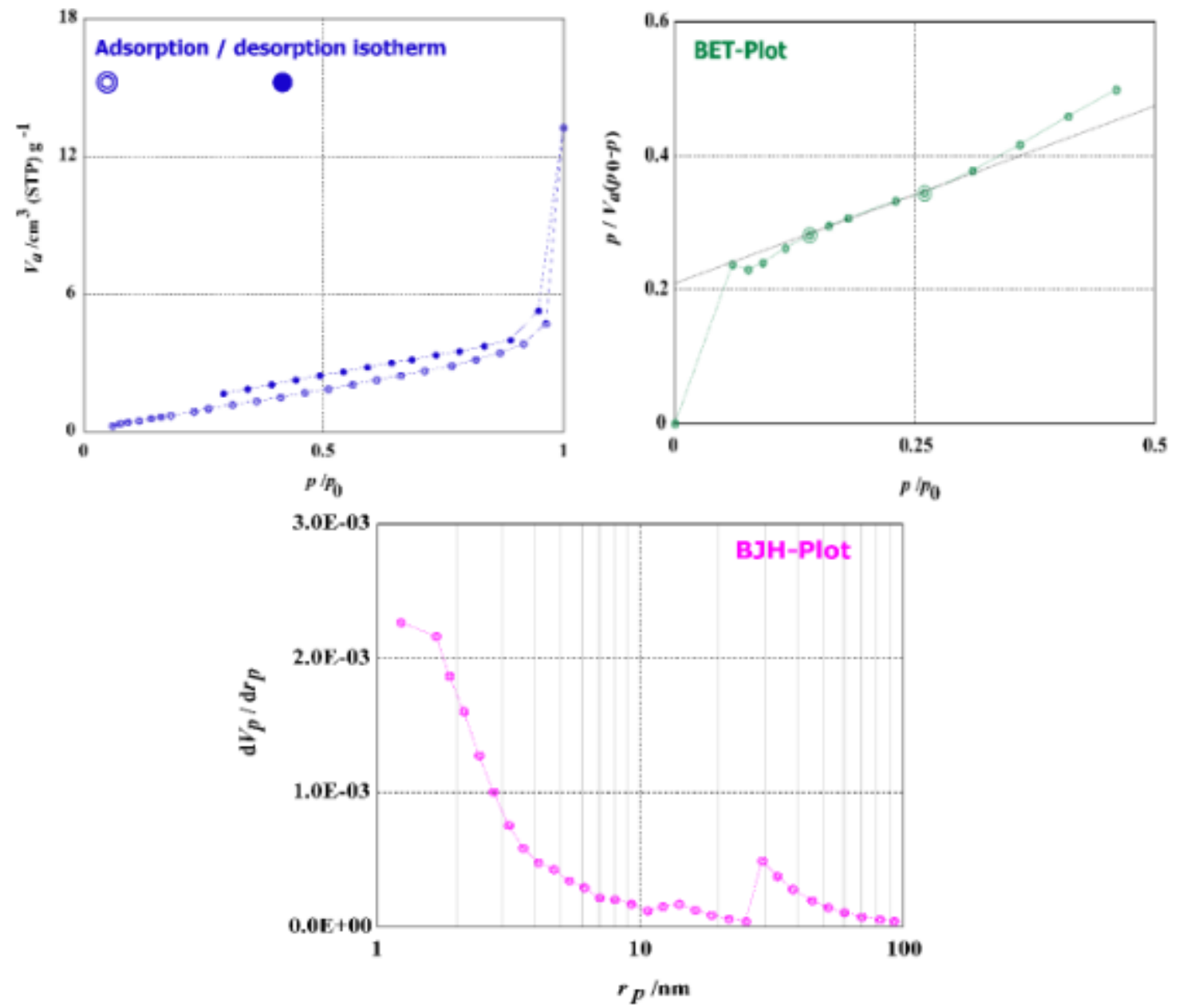

Figure 3

(a) Adsorption Desorption graph, (b) BET analysis graph, (c) BJH analysis graph of MBT. 


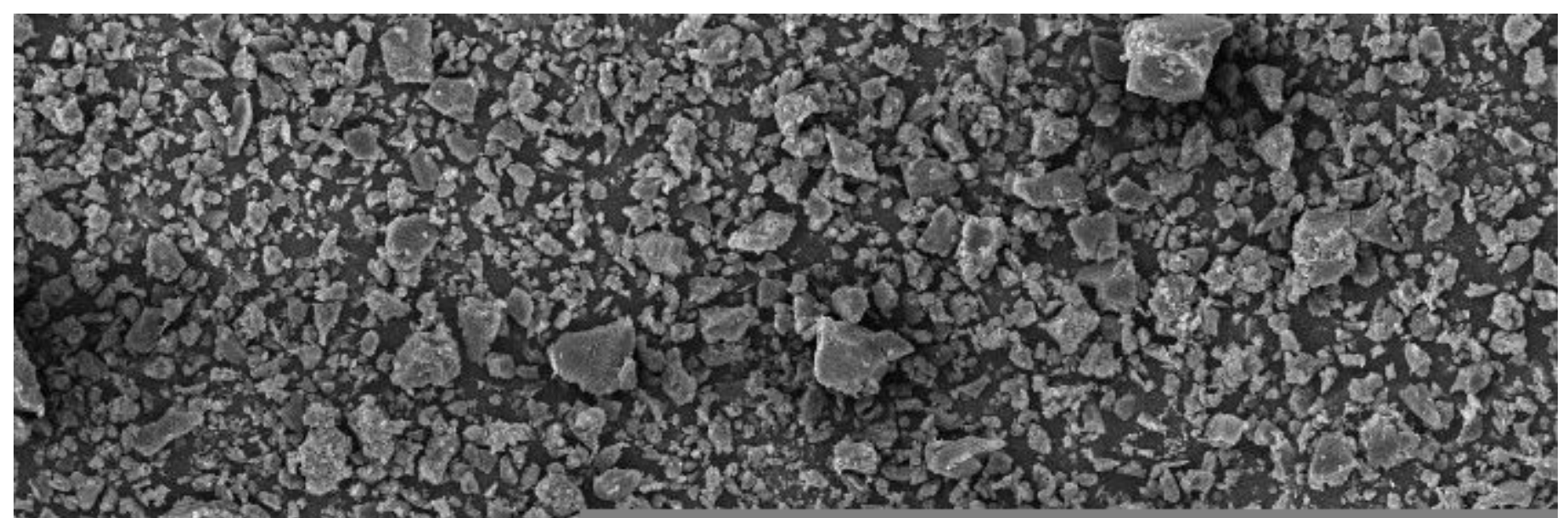

\section{Figure 4}

SEM image of MBT magnification at $\times 200$ under high vacuum. 


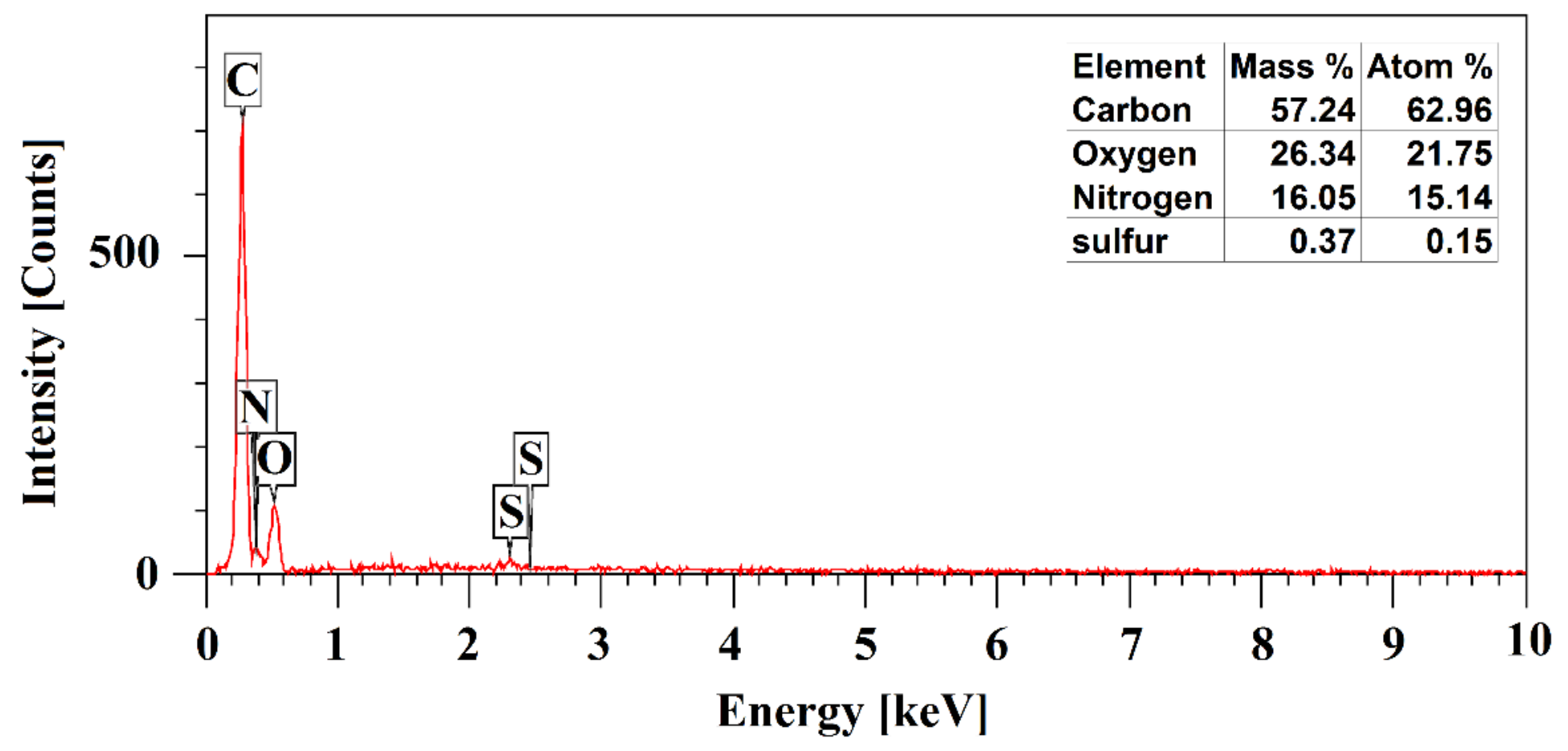

Figure 5

EDX analysis of MBT prepared from Mandarin peels. 


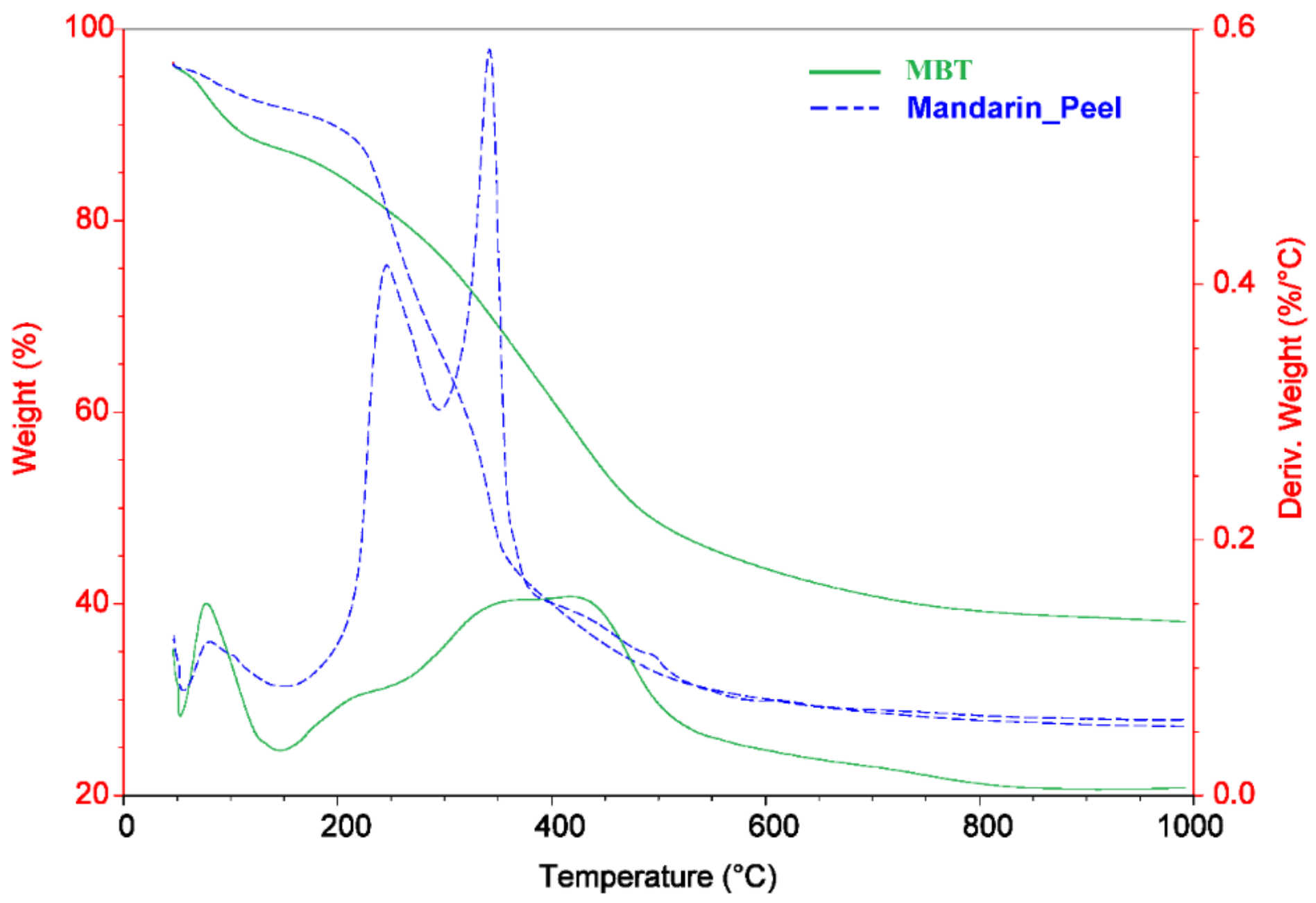

Figure 6

TGA and DTA analyses of raw Mandarin peels and MBT. 


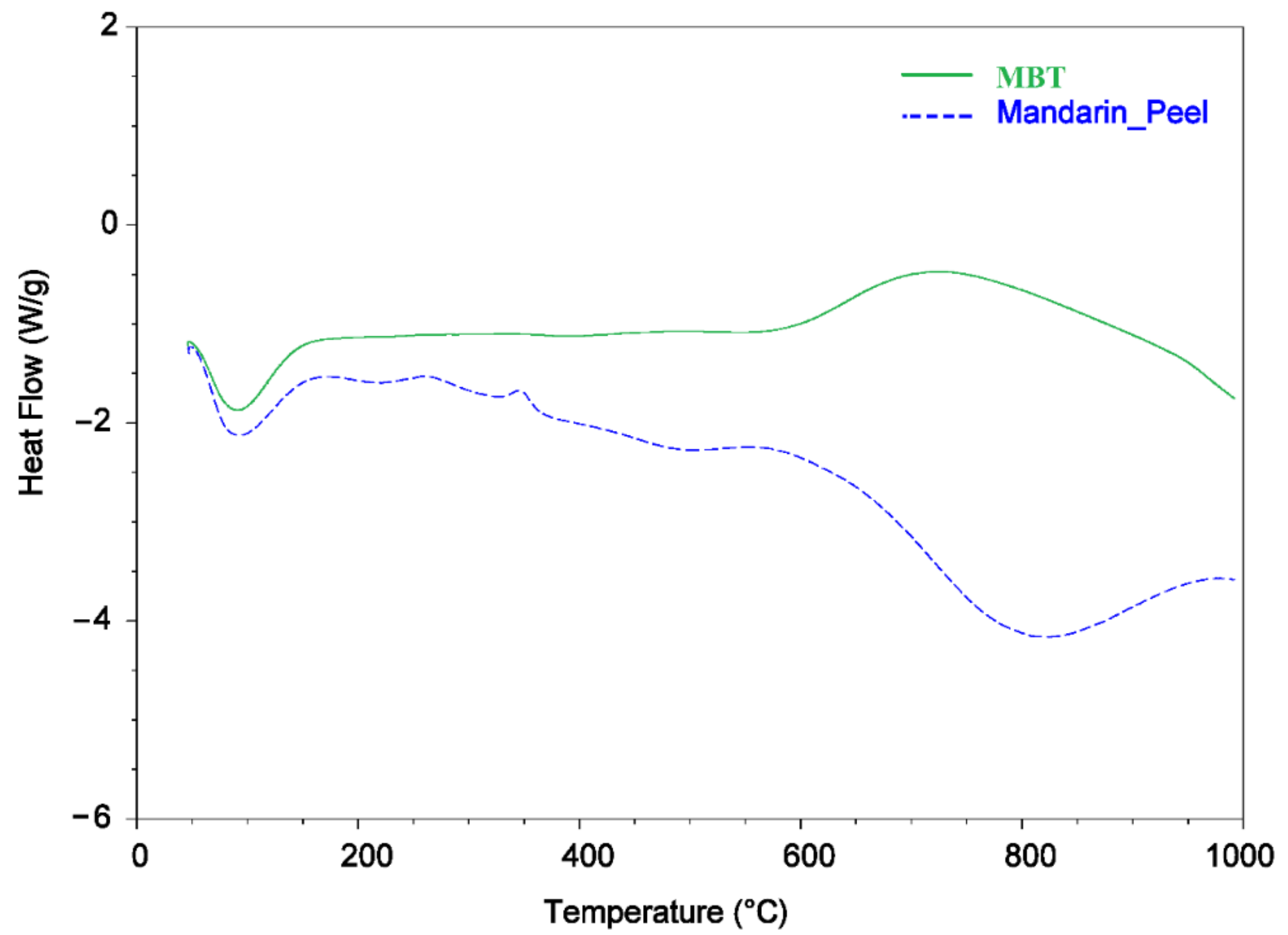

Figure 7

DSC analysis of raw Mandarin peels and MBT.

Figure 8

XRD analysis of MBT. 

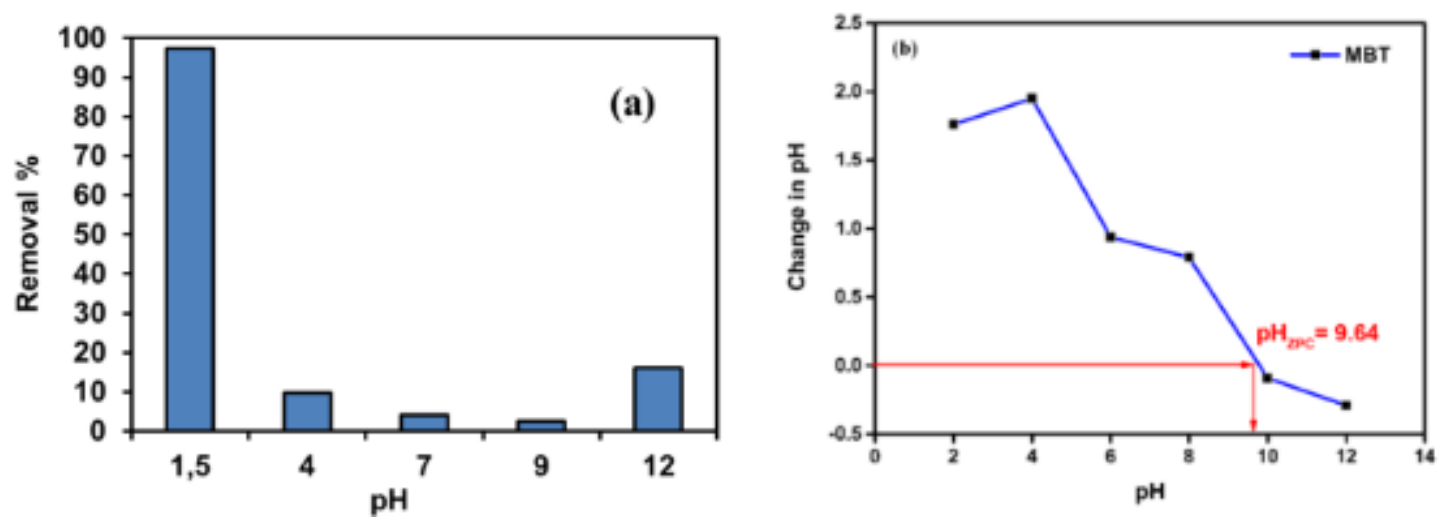

Figure 9

(a) AR35 dye adsorption on MBT as a function of $\mathrm{pH}$ on the removal \%; (b) the plot of $\Delta \mathrm{pH}$ vs. $\mathrm{pH}$ (AR35 dye $=100 \mathrm{mg} \cdot \mathrm{L}^{-1}$, adsorbent $=0.5 \mathrm{~g} \cdot \mathrm{L}^{-1}$, Temperature $\left.=25 \pm 2{ }^{\circ} \mathrm{C}\right)$.

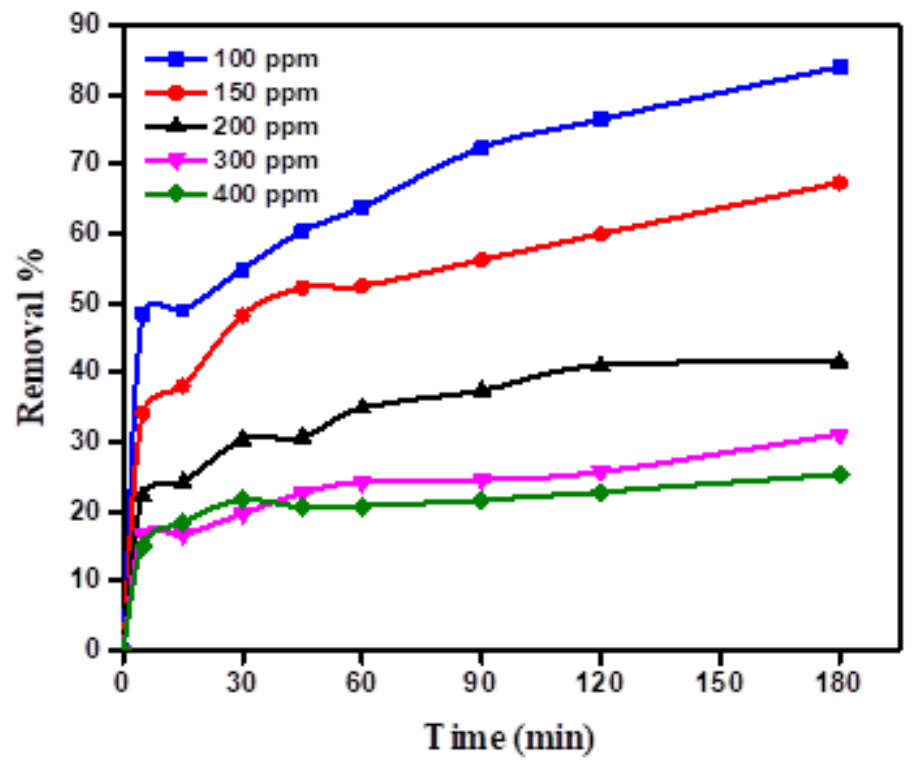

Figure 10

The removal of AR35 dye for the $3 \mathrm{~h}$ using MBT as an adsorbent (Initial concentration of AR35 dye: (100$\left.400 \mathrm{mg} \cdot \mathrm{L}^{-1}\right)$, adsorbent dose $=0.25 \mathrm{~g} \cdot \mathrm{L}^{-1}$, Temperature $=25 \pm 2{ }^{\circ} \mathrm{C}$ ).

Figure 11 
The effect of AR35 dye initial concentration (100-400 $\left.\mathrm{mg} \cdot \mathrm{L}^{-1}\right)$ using MBT doses $\left(0.5-2.5 \mathrm{~g} \cdot \mathrm{L}^{-1}\right)$ on $q_{e}$ $\left(\mathrm{mg} \mathrm{g}^{-1}\right)$ (Temperature $\left.=25 \pm 2^{\circ} \mathrm{C}\right)$.
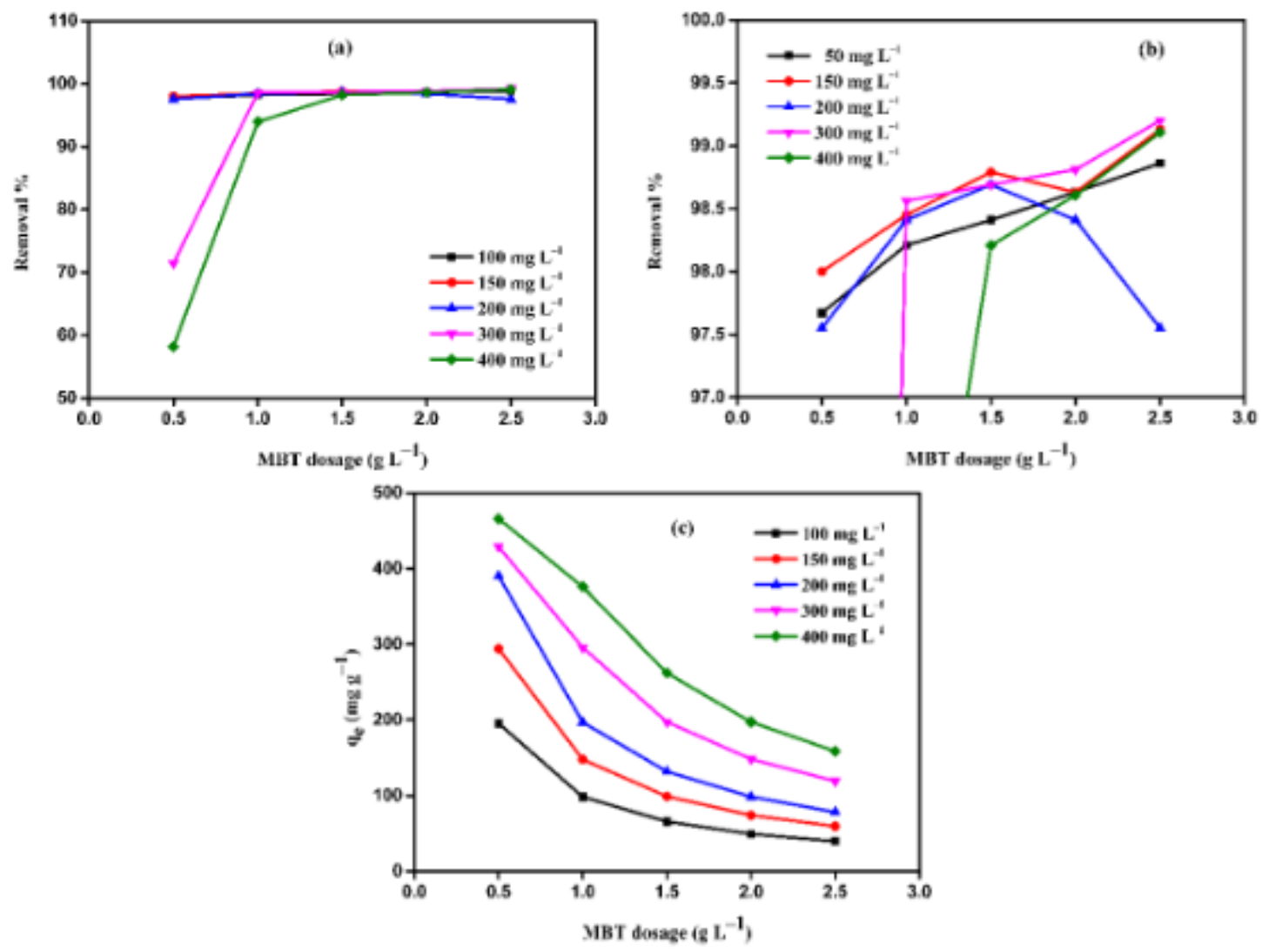

Figure 12

The effect of MBT different doses (0.5-2.5 g. $\left.\mathrm{L}^{-1}\right)$ of different initial AR35 dye concentration (100-400 $\left.\mathrm{mg} \cdot \mathrm{L}^{-1}\right)(\mathrm{a}-\mathrm{b})$ on removal \%; (c) on $q_{e}\left(\mathrm{mg} \cdot \mathrm{g}^{-1}\right)$, (Temperature $\left.=25 \pm 2{ }^{\circ} \mathrm{C}\right)$.

\section{Figure 13}

(a) Linearized Langmuir (b) Freundlich (c) Tempkin (d) Dubinin-Radushkevich (e) Jovanovic isotherms profiles for AR35 dye of initial concentration $\left(100-400 \mathrm{mg} \cdot \mathrm{L}^{-1}\right)$ on MBT doses $\left(0.5-2.5 \mathrm{~g} \mathrm{~L}^{-1}\right)$ at $(25 \pm 2$ $\left.{ }^{\circ} \mathrm{C}\right)(\mathrm{f})$ Comparison between the measured and modeled isotherms profiles for AR35 dye of initial concentration $\left(100-400 \mathrm{mg} \cdot \mathrm{L}^{-1}\right)$ on MBT dose of $0.5 \mathrm{~g} \mathrm{~L}^{-1}$ at $\left(25 \pm 2{ }^{\circ} \mathrm{C}\right)$. 
Figure 14

(a) Pseudo-first-order kinetic model (b) Pseudo-second-order kinetic model (c) Elovich model (d) Intraparticle diffusion model (e) Film diffusion model of adsorption of AR35 dye (Initial concentration 100 - $\left.400 \mathrm{mg} \mathrm{L}^{-1}\right)$ by MBT dose $\left(2.5 \mathrm{~g} \mathrm{~L}^{-1}\right)$, Temperature $\left(25 \pm 2^{\circ} \mathrm{C}\right)$.

\section{Adsorption-Desorption cycles}

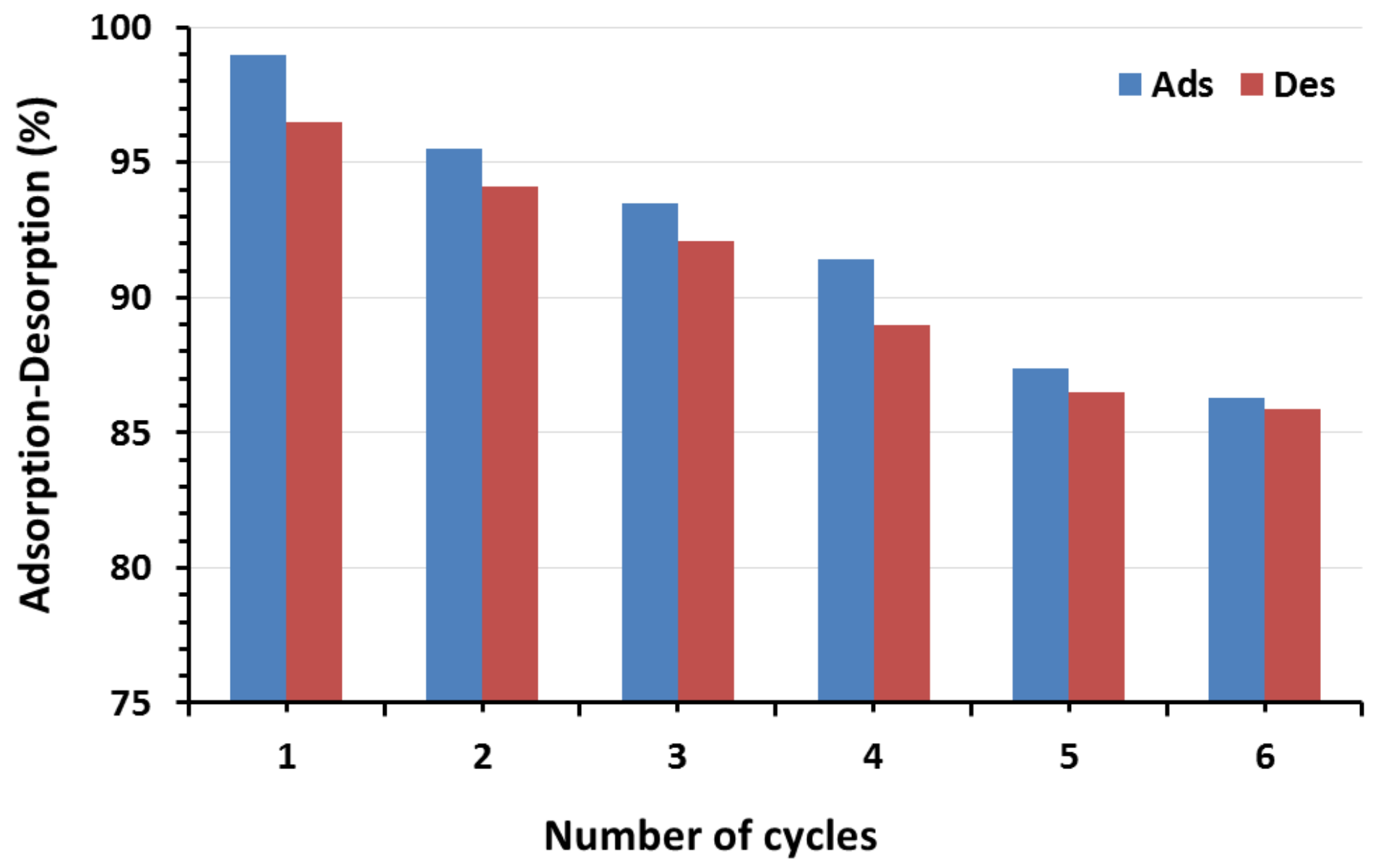

Figure 15

Desorption \% of AR35 dye from MBT using $0.1 \mathrm{M} \mathrm{NaOH}$ and $0.1 \mathrm{~N} \mathrm{HCl}$ and the adsorption cycles of AR35 dye by regenerated MBT. 